Fissay on the Geosraphy, Minoralngy and Bitany of the Western portion of the Territory of the Native Princes of Fava.

A DDRESSED TO THE HONORAELE

THOMAS STAMFORD RAFFLES, LIEUTENANT GOVERNOR OF JATA.

B. Dr. THOS. HORSFIELD.

\title{
SECTION 1.
}

The following Essay contains the substance of the Geographical, M neralogical and Botanical remarks made during a journey through the Western portion of the torritory of the Nutive Princes of Java. It is not necessary for the present purpose to define with accuracy the extent of this territory: it is bounded in the West, the North and the East by the Honorable Ease India Com. pany's possessions, and in the South by the Ocenn. The two Princes are generally known by the titles of the Susuhunan and the Sultan : the enpital of residence of the former is called Sur o. kerto of the latter Joljokerto; the principal sub. divisions of that part of the Island which is occupied by their dominions, will be mentioned in the nexr section: the territory is divided between both, and in the division a principal object has been to allot to each an equal exrent of gromd and the same revenue. 
I have premised, to the detail of the remarks on the subjects above mentioned, an extract of the journal kept during my route, for the purpose chiefly of elucidating the geographical descriptions: this will form the first section: the second comprizes the geographical remarks, the third those on mineralogy, and the fourth those on botany. 1 left Surakarta on the first of Angust.

August 2. The rond from Surakarta to Jokjokarta pervades the most cultivated portion of the antient Mattaram; the tract is, on the whole, level; after a small eminence near the remains of deserted Kartasura, it passes, into the declivities of the mountain Marapi, which is observed, nearly in a North-west direction, at the distance of abour twelve miles. Strangers uniformly admire the surrounding scenery. The prospect is extensive and large: the uniformity of a councry in a high state of culcivation is diversified by the huge cone of the Marapi, towards which the territory gradually rises, and by an extensive range of low hills which appear to meet the road in a Western direcion. Numerous rivers and rivulets descending from the large mountain, cross the road: their current is rapiu, and in their basins are found almost exclusively volcanic materials. They frequently swell after raine, so suddenly as to become dangerous to travellers; mose of them are checked by the Southern hills, and being consequently diverted to the Eastward, fall into the large river of Solo: one principal stream only takes a direction Westward of the ringe of hills, and discharges itself into the Southern Ocean ac Manchingan. 


\section{Essay, E⿱乛龰c.}

Beyond Jokjokarta the large road inclines more to the South, and gradually approaches the shore: I halted successively at Bantul, Brossot and Kadilangu, at ench of which places a Chinese Collector of the Customs resides. European travellers through this part of the Island take their abode, almost necessarily, with these people, where they are, in most cases, received with hospitality. By the frequent travelling of persons on public basiness, through this pare of the Island, Chinese inhabitants are in some degree accustomed to our habits, and it must be acknowledged that they cheerfully contribute what is in their power, to the comfort and convenience of travellers. The first thing which is presented to a stranger on his arrival is tea, which according to the custom of the Chinese is found in readiness at all hours of the day in their dwellings, even in the mose distant parts of the Island: and from the quality of this article some estimate may usually be formed of the condition of the inhabitants. About the time of their ordinary meals, the traveller is always liberally supplied with the common food which serves for the family, buc those articles of convenience and luxury to which Europenns are accustomed must be provided by himself: in exchange for the comfort or assistance he receives, he must generally submit to an interrogation from ali the inhabitants of a dwelling; and these are often importunate and troublesome: The object of his journey is minutely enquired into, his baggage is reviewed with a curious attention, and every novel or uncommon object becomes the subject of particular disquisition; 
if the traveller is a man of rank, his attenclants and servants must expect to be interrogated and examined in his place.

On entering the compound of the Farmer of the Customs at Bantul, I observed abouc half a dozen large game-cocks under appropriate cages, whose constant clamour and cackling appeared te be pleasant and agreable to all the inhabitants of the house in the same degree in which it was annoying to me: I soon perceived that they were objects of particular attention and carefully fed at regular periods. Every person accustomed to the intercourse with the natives, whether in the interior or along the seacoast, knows that cock-fighting is one of their common diversions, and even where chese animals are not kepe for this purpose, several large cocks under spacious cages or rather baskets are constantly found arranged at certain distances around their compounds. It is probable that the Chinese have adopted this amusement from the Javanese, but $I$ afterwards found it universal among them on the route though this part of the Island. In the vicinity of the capitals, the Chinese Farmers follow the mode of life of their inhabitants, and the dwellings are supplied with various articles of house hold furniture, buc in the distant forms, chairs and even tables are generally looked for in vain.

The dwelling of the former at Bantul indicated some taste and neatness; being a native of the Island, of Chinese descent he has like many orhers of this description (who are denominated peranakans) imitated the customs and mode of life of Europeans. At Brossor a lodging-house, passangrahan-is provided for the 
convenience of the traveller at some distanee from the dwelling of the farmer; it is in a pleasant situation, cleanly, and supplied with the various necessary articles of furniture, but at Kadilang $u$ he must accomodate to the inconvenience and offence of a bambu shed, crowded with numerous Chinese inhabitants.

August 5.-At Kadilangu I left the common route along the southern shore, and proceeded in a north-western direction towards the interior; I crossed the large river of Bogo-wonto several miles above its discharge. A branch of the grand ranges of central Hills, here extends considerably to the south, and the river often winds near the foot of the most projecting points. I breakfasted at Bubutant, a small farm belonging to Kadilangu, and passed a Bazar, called Jennér about 10 o'clock. Here I observed the principal points of the branches of Hills descending in this direction, to which the road very gradually approaches, on the route to Jonno, where I arrived about 2 o'clock.

Fonno is the most considerable mart for the various linens which are manufactured in considerable abundance in this part of Baggalen, and well known in the surrounding districts on account of the quantities which are here offered for sale at certain days in the week. The whole of this province is celebrated for its manufactery of Cotton; wherever the soil is favorable this article is cultivated, but much more is required than the country produces, and the dificiency is supplied by the neighbouring province of Banyu-mas. On my further route I frequently met transports of Cotton proceeding to the Bazar of Jonno. The trade in this ar- 
ticle, whether raw or manufactured, is chiefly engrossed by the Chinese; and a number of them havepermanent residencies at this and the neighbuuring Bazars: Several of their dwellings at Jonno are built of brick, and resemble those of the more wealthy inhabitants at the capitals.

A branch of the river Bogo-wonto, the river Fali, passes through this Bazar, and during the rainy season the whole surrounding territory is completely inundated: the incercourse with the neighbouring villages is now carried on exclusively in small Prows or Canoes, and affords on Bazar days, a very pleasant and lively scene,

August 6. - Went on to Weddh, a considerable village and Bazar at the western extremity of Baggallén. About half way (from Jonno) the village of Gebbang is situated on a river of the same name, in the vicinity of which numetous plantations of Cotton are laid out; the course from Jonno to Weddî is nearly directly west. Between Gebbang and Weddî I met numerous traders returning to the capital with the linens purchased at the bazar of this day.

Weddì is, next to Jonno, the most considerable mart for linens in this Province; it belongs to Surakarta, while the former is attached to Jokjokarta. I observed during a walk in the afternoon, many of the female inhabitants carrying loads of red yarn, elegantly colored of a deep scarlet. It was brought to the farmer of the Customs for the stamp or licence required to offer it for sile at the bazar. This yarm is died by the Morinda Citrifolia, the Bengktudtu of the Javanese, or by a discinct species of this genus which is cultivated as an under-shrub. 
August 7.-On leeving Weddi I took again a southern course towards the road leading from the capital to Karang-bollong. After crossing the river of Lerreng, which at this time of the year is small and confined, but in the rainy season contributes principally to the intudation of the surrounding territory, I arrived at $N$ gambal, a small village and tract near the large road, and further westward observed Banjur, Botshor, and several other large villages. About noon I reached Ledati, a small farm, a dependency of Weddi.

August 8.-I proceeded on the large road, to Patanaün, and consequently to Kaleng and Wetton: the tract is nearly level, but on leaving Wetton one observes distinctly the transverse ranges of hills which contribute to form the peninsula projecting in this part of the Island. About noon I arrived at the river Chichinggoleng, which winds at the foot of the hills, and at the extremity, a few hundred yards Souch from the road, discharges itself into the Ocean. Several small villages are dispersed through the neighbourhood, the inhabitan:s of which assist the trave ller in crossing: the river is very eep and the sea beating in from the south, occasons at times considerable roughness; two or three small canoes are attached to each ocher by means of a rafe of plaited bambu, on which the passengers and goods are conveyed across. On the opposite side the ascent is at once precipitous, and the constitution of the hill is found entirely different from the low trace through which the road has hicherto passed. After the first ascent and an oblique curve of about half a mile along the western slopes of the first ridge, one meets 
in a valley, ransmitting a small rivulet, the principal village on this peninsula, denominated Karang-bollong. From Surakarta to the river Chiching-goleng, the road passes, with few exceptions, through districts which are cultivated: a greac proportion of chese are low, and rice raised on inundated grounds, (Padi-sawa, ) is the chief production. In some parts of Bnggalen this grain is sowed on high grounds, elevated beyond the point that is inundated during the period of the rains, and in rotation with various other vegetables which are employed in the food of tho natives: these are principally Legumes of various kinds, Cucumbers and other cucurbitaceous plants - Roots (Dioscorea, Convolvuli, \&c. ) and many others. Favourable situations produce Kachang-china (Arachis Hypogaea) Indian-corn and Cotton. But in many of the fields which I observed the soil is composed almost purely of clay, withour any mixture of sand or mould, bursting widely during the hot season, and only accommodated to the production of one crop of rice, on the retirement of the inundation caused by the rains.

August.9.- Was devoted to the examination of the hills in the neighbourhood, and to a visit to the caverns in which the Hirundo Esculenta builds her nests. These caverns are found, at intervals, along the whole of the southern coast, from Java Head to the extreme eastern point, but no part of the Island contains them of the same extent or so well supplied with inhabitants, the circumstance on which their productiveness depends. The object of my visit was to determine personally their mineralogical constitution, as my ideas had hitherco been formed alone 


\section{Essay, Eंc.}

from the analogy of similar caverns in other: parts of the Island, in which they are formed almost exclusively in calcareous rock; and it will be necessary, consequently, to modify a remark made in the first part of the mineralogical essay. In regard to the particular economy of this bird, his food, and the manner of constructing the Edible Nests, as weil as substance which furnishes the mateials, much remains still to be ascertained.

The peniusula which here projects to the souch beyond the common range of the coast in this part, consists of several successive ridges running parrallel, almost directly north and south, and terminating precipitously at the Oceail. At the extremity they are divided by numerous clefts or fissures, which penetrate into the body of the hills, and in many instances extend, with various windings, to a considerable distance. Their direction in general is vertical, the horizontal diameter being the smallest, and they are closed above by the same mineral substance which forms the body of the hill Many of these fissures are in contact with the Ocean, the water of which occupies the lower portions: in these cases the external openings have remained complete, while in more inland situations, the hills of which we may analogically suppose to be cleft in the same manner, the apertures have been closed by de-composing vegetables or mincrals, and the fissures to which they lead are concealed.

The apertures of those caverns which are at he present period most productive in Bird's Nests, are situated at the battom of precipices whose perpendicular height is between 50 and 100 fathoms: they are narrow, and have the 
same vertical disposition as the caverns; the water of the Ocean enters and retires with the tide, beating violently against the rocks which compose them, and at certain periods, when the waters rise above the common standard, the access to the caverns, always difficult and dangerous, is entirely impracticable. When this occurs during the period of collecting the Nests, it proves a great annoyance to the natives who are employed in this business.

The collection of the Bired's Nests being a very hazardous office, is effected by the inhabitants of neighbouring hills, who are accustomed to it from their infancy. They are denominated Tukans, the general term, in Malay, of a person exper in any particular business, or exercising a profession. The descent to the external aperture is performed on a ladder of Rattan, resembling in some degree the Shronds of a ship, attached to a rock, tree, or other fixed substance from which it depends perpendicularly. Although the length is in several instances very considerable, the descent and the return, even to a person carrying a load, is considered a crifling enterprize in comparison with the gathering of the nests from the sides of a cave: for this purpose bridges, often of considerable length, are constructed of the entire runks of Bambu, which are placed together longitudinally and transversely, and fastened to each other by rattans; a support to the hand of the collector is afforded by a separate rattan, of a large size, extended parallel to the bridge, about half a man's height, and answering to the railing commonly employed as a support across a narrow or: difficult passage. These bridges are attached 


\section{Essay, Ė.}

to the projecting Stones of the Cavern, and their fudicious regulation and distribution is one of the most important and hazardous duties of the office of a Tukau. If a collector misses his hold, or if the bridge which he traverses s.parates or breaks, he is inevitably lost. No exertion of his fellows can save him; if in his fall the should escape the sides of the cave, the vialent agitation of the ocean at the bottom would infallibly dash him against the rochs.

Having visited the Caverns in the inmediate vicinicy of Karang-bollong, I pursued my course in a Western direction, across the successive ranges of hills, to the souch-west extremicy of this peninstala: at the cavern of Nagassary the declivity was sufficiently gentle to enable me to descend to the bottom, to observe the external aperture distinctly, and to examine at leisure in contact with the ocean, the materia's that compose the extremity of the hill, A large yertical section was here exposed, and exhibiced very strikingly the disposition of the strata which I had previously traced at the surface, As certain periods, when the ocean in not much agitated, it is not difficult to descend to the entrance, from this pile of rocks where 1 observed it, which is descripcively by, the Javanese, the Pagelaran or outer-apartment of the cavern. The particular constiturion of che rocks will be described in the Mineralogical account.

After a visit to Fingkla, I descended on the Western side of the Peninsula, into the plain near the Eastern boundary of the district of Aycs A small Chinese Farm called Fitis is situare 1 here, and a few inconsiderable villages are 
dispersed. The rest of Aya, in this part, is a desert, overflowed during the rains, marshy at all periods, and rendered almost inaccessible by an excessive luxuriance of an useless and unproficable vegetation. At the foot of the ridges a considerable river, called the river of Aya, discharges itself into the ocean, near which, about five miles inland, the village of Pringtuttul is situated, well known as the place of banishment of offenders or rank from the court of Surakarta, and particularly of such as have incurred the displeasure of the Sovereign, by real or supposed treasonable conduct. This village is situated in a large forest, surrounded by marshes, and in a high degree solitary and gloomy. I observed in the Inhabitants of the neighbouring district a mode of dress, which is not common in the more populous or polished districts: in place of the common habit or vestment, consisting of a broad strip of Linen, denominated Sarong or Long-cloth by the Malays they wrap a similar strip of Strawsack or Karong about their Loins, which gives them a disgusting and savage appearance, and their manners appeared to partake in some degree of the apparent ferocity of their dress. The carried on their conversation with an uncommon vociferation; but they deserve consideration both on account of the wildness of the district which they inhabit, and of the dangers and hazards to which those are exposed who inhabit the Hills and assist in collecting the produce of the caveras. They have a particular method of carrying their common iron utensils or hatchets, used in cuting trees and for varicus domestic purposes; these they place 


\section{Essay, Éctc.}

In a square wooden sheath or rather box, suspended by a girth at the lower part of their backs, which produces a rattling noise in walking and moving; on the sculpture of this box they display the utmost of their skill; in several instances the fragments of a broken looking glass were employed to increase its beauty.

After my return to Karang-Bollong I visited several of the chief villages of this neighbourhood; they are in general small and dispersed through the Hills: they have no (or very confined) Rice-gronds, but are plentifully supplied with Cacoa-nut and other Fruit trees. The common domestic aniffals which serve for the food of the natives, Goats, Fowls, Ducks \&c. are very cheap, and rice is abundantly supplied by the neighbouring districts of Baggalen. The name of Karang. Bollong is derived from an excavation or vault in the extremity of the hill, near the discharge of the river Chichinggoleng; this is mentioned in the subsequent sections. A bouth two miles Westward of the chief village, the ridges are intersected, at the ocean, by a considerable bay, denominated the Bay of Passir, near which $W_{0} l l l o_{0}$ and various other small villages are pleasantly situated.

Agust 14-I continued my route directly north along the ridges which constitute this peninsula; I halted at Rangka, a small district belonging to Baggalen, completely level and covered with villages and rice-gronds.

Agust 15. - I made a diversion fron the common road, and visited the principal village of the district of Roma, called fati-nzogoro: the tract is level and in a high state of culture, buc not far to the northward the summits of the cen- 
tral runges are discerned, Hence I took a west erin currse to Selondokko, a village near the northern confines of the district of Aya. Several miles beyond Jati-nogoro the road meets the hills descending from the numerous central ranges, and the environs of Selondokko are already very uneven and separated by a succession of ranges, gradually rising to the north, from the Jower district of $\mathrm{Aya}$, in which Pring terteul and Doplang are, in a southern and southwestern direction, solitary hamlets. Through the neighbouring hills of Selondokko numerous small villages are dispersed, the inhabitants of which cultivate "Crogos" or mountain rice. The soil is a black mould and highly prolific. The improvement of this neighbourhood is progressive, and the population gradnally increases.

Ausust 16.-On the further rouse the uneven ness of the territory increases; after passing several rivulets which take a southern course, $\mathrm{I}$ arri ed at the foot of the hill Chelenan, the ascent of which is long and considerable: on the summic a fine prospect of the surrounding country is afforded; I noticed the direction of Pringturtul and Jitris, and the south-west extremity. of the peninsula of Karang-bollong a accorting to the usual custom, a simple break-fast was here provided, in the native style, for our pary by the inhabitants of the surrounding villages, under the shade of several ancient Warringin trees, which aflord a convenient and pleasont resting place to travellers; and the long-continued ascent, from troth sides of the hill, renders the sicuation peculiarly desirable as a place of reireshment. The descent in the north is interrupted by repeated ravines; having passed: 
several, a wide prospect opens in the north: an extensive portion of the grand central valley displays the windings of the river Serayu, beyond which the ranges in the north are observed to rise towards the large Mlomtain of Tagal: as one proceeis in the deseent, the situation of the capital of Banyu-mas is distinguished by a close forest of Cacoa-nut trees. - I arrived here about 12 o'clock.

In the immediate environs of the capital a considerable tract is appropriated to the support of the Tommong-gong or native governor of this province, while the greatest part of the revenue of the principal sub-divisions, which are mentioned in the next section, are yielded to the Sovereign. The share of the Tommong-gong amounts to about one-fift of the whole proceeds of the province; besides this each of the divisions has a particular native chief, who administers his respective district, but is subordinatie to the Tommong gong.

The eapital of Banyu-mas is situated on the banks of the river Serayu, being regularly laid out and divided by broad roads, crossing ench other at right angles, and bounded by a high fence of bambu, beyond which the dwellings of the inhabitants are disposed without order; each family has a parricular alletment of ground or square which generally is surrounded by a separate enclosure. The dwellings of the Manteries and other principal inhabitants are only distinguished by the external gateway, being more conspicuous, and, in some cases, ornamented with rude sculpture. I could obtain no satisfactory information as to the rumber of in habirants of th capical, or racher principal yillage; ne acearate: 
enumeration has yet been made; according to: vague escimate it contains between 3 and 4000 Souls. The Chinese inhabitants live separately on the banks of the river, near the farmer of the customs. The name of the village and the whole province is said to be derived from a small rivulet, which pervades the southern portion, and unites to the Serayu near the partinhabited by the Chinese, denominated from time immemorial Kali or Banyu-mas.

August 20. - I left the chief village to visit the South-western districts of this province: my course was first in a southern direction. After passing the narrow plain which bounds the banks of the river, and is laid out into rice plantations, I crossed a branch of the central hills running off in a South-western direction, consisting of numerous smaller points aggregately called the hill of Kali-weddi.

This range, as well as that between Selondokko and the capical is covered with a luxuriant vegetation, differing from the wilderneess of the lower tracts; it furnished me with various new subjects which will be mentioned in a succeeding section. It likewise afforded an excellent opportunity of noting the gradual succession of various vegetables according to the point of elevation. At one of the southern declivities of the separate hills, almost the whole of the district of Aya was exhibited to view. The extent of coast from the peninsula of Karang-bollong to the hill Bedu-gangan was distinctly scen; the surf beating against the shore, appeared like a white band, and formed a highly pleasing spectacle. On leaving the range of Kali-weddi, one descends into the plain of Aya, which in this part is 
not subject to long continued inundations and affords many sicuations fit for culture. I met with several villages near the banks of the Serayu, the curves of which often meet the road.

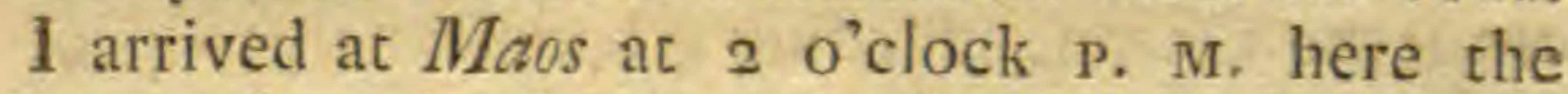
state of cultivation grandually increases. Penggalan, whither I proceeded the next morning, is likewise a flourishing village, and the environs of Adipollo, Adiridsho and Adirodsho, are nearly in a complete state of culture, comprizing a very extensive tract, which is laid out into rice plantations, and on the whole favourably situated for an annual crop. This portion of Aya forms a pleasing contrast with the neighhourhood of Fittis in the east, and that towards Talachap in the west; but towards the acclivities of the ridges in the direction of Pringtuttul and Doplong, the territory is again covered with a wild, and, from its distance, unproficable vegetation.

August 22.-I went on in the morning southerly to Bunton, situated near the Ocean at one of the former outlets of the river Serayu, which is now completely shut up. The discharge of the river is about one mile further westward. The passage across is effected in the same way as above mentioned at Chiching-goleng: the canoes or boats were larger; the raft of bambu, secured on two of these, had firmness enough to support several horses. Near the western banks two inconsiderable villages are situated, beyond which this part of Aya is a continued desert to Tala-chap, a small settlement, near the boundary of the Honorable Company's possessions under the Residency of Cheribon, opposite to the eastern extremity of a small 
Island, distinguished among the natives by tha name of Nuso Brambang, and by perversion generally called Nuso Kombangan. The road follows the direction of coast, and ofcen comes outat the Ocean, affording a handsome prospect of the Island just mentioned in the west: vegetation is on the whole more diversified and interesting than in similar siruations, and I collected several, subjects which will be ment tioned in the botanical section. I arrived at Talachap about one o'clock. This neighbourhood contains now the remnant only of a once flourishing settlement: it has been nearly ruined by the repeared visits and depredations of the pirates, arriving (probably) from the Islands of Ling a, Riouw, and several others near the southern extremity of the Peninsula of Malakka, well known for their nautical enterprizes. It is painful to observe, on the spots of the former villages, nothing but the indications of a more flourishing period. Extensive clusters of Cacoanut trees still remain, of others the decapitated stumps only exhibit signs of the wanton licentiousness of these adventurers. The frames of several of the principal houses are observed above the high grass with which the ruins of the villages are covered. During the last twa years che settlement has again in a small degree revived, and several of the former inhabitants have returned: to this has chiefly contributed the security and protection which is afforded Ehem in various ways by the Btitish Government: not only by the establishment of at stockade or small fortification on the north-eastern point of Nuso-Brambang, commanding the enfrance of the Strait which is formed batween 
this Island and the const of Java, and leads to an extensive bay at the southern part of the dis. trice of Sukapura, called Segro-anakan, bus particularly by keeping in awe the pirates from the Islands above mentioned, and those Malay Princes who are in the habits of supporcing them. The visits and enterprizes of the pirates were not confined to the neigbbourhood of this settlement: by ascending the rivers which discharge themselves into the strait and bay, they proceeded to the center of the Island, Sukapura. Dayu-luhur, and Juruk-leggi were equally exposed to their invasions. Many of the inha. bitants were carried off in slavery, or oblised so retire to places of greater safery, and the villages were plandered and destroyed.

The situation of Talachap, though pleasans and interesting on account of the prospectitaffords to a temporary visitor, is by no means desirable as a permanent residence. The exhalations from extensive swamps which surround it; occasion remittent bilious fevers, which carry off mony of the inhabitants: there is likewise a deficiency of rivers and rivulets of a moderate size, for the purpose of laying out rice-gronds cultivated by inundation. In the course of the following days I visiced the remains of a former settlement at Donosin, near the discharge of the river of Juruk-leggi, the Strait runnin y towards Segoro-anakan, and an extensive range of the opposite coast of Nuso-Brambang. On the $24 \mathrm{th}$, I: returned to Adipollo.

- Within the distance of three miles, the three principal villages of the district of Aya are situated; Adipollo, Adiridsho and Adirodsho.

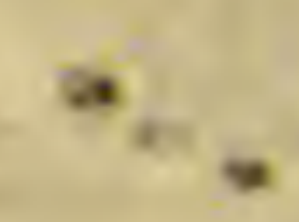


river of the same name flows by the latter, and discharges itself into the Ocean at the foot of a transverse ridge of hills, which has the same direction as the Peninsula of Karang-bollong: its constitution is likewise similar: it terminates precipitously at the Ocean, and contains a cavern which is inhabited, although sparingly, by the esculent swallow. The district of Aya is at present administered by two chiefs, under the superintendence of the Tommong-gong of the province, who have the tirle of Ingebey or Behi : one of these resides at Adipollo, the other at Adiridsho. I returned to the capital by the same road, and after the arrangement of my plants, and the completion of the outlines of vas rious drawings, I prepared for an excursion in a different direction.

I crossed the river of Serayu near the dwelling of the Chinese farmer of the Customs at the eapital, and went on directly north about three miles to the large village of Suka-rodsho, situ. ated near the enstern boundary of that subdivision of the province which is denominated Passir. After a considerable acclivity, about of a mile beyond the river, the tract is nearly level, rising very gradually towards the large Mountain of Tagal, situated north-west from this place at the distance of about 8 miles. The environs of Suko-rodsho are at present in a very flourishing situation; the villages are large and surrounded by extensive plantation: various ridges, connected to the central hills, appear at a distance; many of these have also been cleared for plantations of Mountain-Rice and Cotton. Dumeraus rivulets and rivers descending from the large Mountain irrigate this and the adjae 


\section{Essay, E'c,}

cent districts. I went on from here to Purwo: kerto, the chief village of the district of Passir; the country here is in an equal state of culcure and scarcely perceptibly rises towards the north. The cultivation extends to the foot of the ranges in the south, beyond which several viilages are dispersed; the chief of these, in a district of the same name, is furuk-leggi.

September 8. - l proceeded in a western direction: the territory is cultivated in the same degree as that which I passed yesterday; two large rivers, besides numerous smaller streams, descending from the northern hills, afford a plentiful supply of water: abour six miles west ward of Purwo-kerto, the road gradually ap. proaches the branches of the central ranges running out in this direction, and inclining, in the north, to the western declivities of the large Mountain of Tagal: from the foot of these hills to the westward, the degree of cultivation gradually dimmishes, and the tract becomes uneven, but a considerable settlement exists at Atshi-barang, where I arrived about noon.

Adshi-barang is a small district stretching westward to Dayu luhur which is situated at the furthest boundary of the possessions of the native Princes; this tract is rarely visited by the inhabitanes of Banyu-mas and Adshi-barang; I could obtain little satisfactory information concerning it: it is described as being covered with forest, deficient in population, and almost inaccessible on account of the imperviousness of the roads.

The settlement of Adshi-barang is improving; the villages are chiefly laid out in the vallies between the ridges, which transmit nus 
ble from the capital, I deferred the minute investigation to another opporcunity, after my return from the wes ern divisions of the province; I therefore went again to the principal village on the southern declivities of these ranges, and during various leisurely excursious, collected from the hills which are still covered with the original stock of vegetables, many interesting objects: these are enumerated in the catalogue of plants, and among the trees and shrubs, many remain for future investigations.

When I first arrived at the capital of Banyumas, the Tommong-gong or native governor was still at the court of the Susuhunan, but his recurn not long after my arrival, towards the end of the month of Ramadan of the Arabs, uniformly denominated Puwasa by the Java: nese, tended both to facilitate my researches in his districts, and to afford me an opportunity of noticing some peculiarities in the mode of life and the government of the natives in the distant provinces. To detail these would be foreign from my object at present: it is sufficient to obselve that the life of a large proportion of the subjects of the native princes is divided into two periods-one portion is spent at the court or residence of the sovereign, and devoted to his service; during the other they are permitted to return to their ho mes, to culcivate their plantations, and to prepare for the next period of service at the capical. Persons of rank and distinction are attended by their wives and families; but among those of the lower order these are necessarily employed in cultivating those grounds which are allorted to their support. These periods are in genaral nearly equal; bus 
they depend, in a great measure, on the pleasure of the prince, and on the urgency of those duties he chooses to impose upon them at the capital.

The Tommong-gong had arrived about 8 days before the feast celebrated on the lasc day of the month of Ramadan. Having recurned from one of my excursions on the evening immediately. preceding that feast, I could not excuse myself from being present at the entertainment, which was, as cus omary, given after the more serious ceremonies of the festiv 1 had been gone truugh. The numerous relations of the native governor, who are mostly employed in the various offices of this province, tended to give a greater degree of vivacity to the celebration than might be expected in a distant village: in every thing the customs of the capital were imitated, and under the idea of paying respect to the sovereign, the Tommong-gor g received that abject reverence which contributed to give him the appearance of a prince. This is the case in all the distant provinces, and perfectly consistent with the Javanese Government or despotism; and even Ingebeys and Demangs exhibit, on these occasions, not a li tle parade.

In the course of my continuance in this pro. vince, the Tommong-gong was zealous to give me every assistance in the prosecution of my researches: travellers depend, in the districts of the native Princes, on the good wil of these people, altho' this is obtained by the recommendation of the prime minister at the court, and the mode of travelling necessarily followed in a country where the oriental and feudal customs prevail in their full extent, affords many instan. ces of the dependence on the character of the 
chiefs. Nothing can be obtained by a pecunis ary emolument, unaccompanied by the order of a chief, and force has often occasioned a remporary desertion of the inhabitants.

In my return 1 followed, to Segalo, the large road leading from Banyu-mas to Surokerto; Purwo-rejo and Comuro are, in the province of Banyu-mas, the principal villages on this road; the last belongs to the district of Banjar: Kutto*aringin is a considerable village at the eastern extremity of this district. Here I left the large road and went on in a northern direction, crossing the large river of Serayu a few miles before the influx of the Merawu. Between Gomurru and Kutto-waringin 1 had a favourable opporo unity of taking the Mountain of Tagal, the Sundoro, and the Sumbing, into one point of view, and to determine their relative situation.

October 18. - I halted at the principal village of the District of Bandshar, near the foot of the ridge of hills which rises again to the North of the valley that transmits the large river: it is situated near the banks of the srream Merawu, above mentioned, and contains, according to estimate, about 1000 inhabitants. The roads passing through this village are broad and regular, resembling in their distribution these of the capital of this province. This village appears to be: in a prosperous condition, the environs are fertile and well watered, and the culcivation is luxuriant.

In departing from the large road, my objecs was tu investigate the extensive ridges which occupy this part of the Island, and to traverse a zract which promised a greater abundance and variecy of vegetable productions than could be expected on the common route. 
S October 19.- I proceeded from Bandshar Northward: the road first inclines to one of the most considerable points of the central ranges the hill Pawinian (the situation of which is noted on the Map, and then passes between this and a very steep; conspicuous pile of perpendicular rocks, called Gunung Lawet; it consequently winds round the Northern declivities of the hill Pawinian, towards the Western extremity of which I entered the District of Karang$K o b a r$, and halted at the small village of Pagger-pella.

The District called K Karang-kobar occupies a considerable portion of the central hills : these are here very mulcifarious, of very different extend and elevation, running into each other without exhiniting any regular distribution. Their general direction is from North East to South West, which is also indicated by the course of the rivers. They are very instructive in a mineralogical point of view, and their constitution will be explained below. Travelling in these parts is by no means facilitated by the condition of the roads; a path, following the windings of the hills, generally leads from one village to another, but where the tract is cultivated, the traveller must find his way over the mounds which separate the rice fields. To any enquiries on this subject, the inhabitants coolly reply that roads would be of little use to them and not reward the trouble of making; and as there are no native chiefs of superior rank who travel trough this district, the influence of the separate Demangs, between whom this tract is divided in small portions, is insufficient to ex

\section{$\mathrm{N}_{2}$}


cice the whole population to the improvement of the roa's. On this account, as well as to obtain more time for botanical and mineralogical researches, I went on only a few milcs every day. After laving Paggar-pella, my next halt was at Karrang-kobar, the chief village of this district, situated in a concavicy, surrounded on all sides by small rounded bills. The climate here is cool; from the chief village of Bandshar, sitnated near the river Scrnytu, in the lowets part of the centre of the Island, the country gradually rises towards the North. The soil is fertile and produces abundantly, but the trade wich the neighbouring districts is not considerable, on account of the distance of a market, the condicion of the roads, and various other impediments.

October $21 .-1$ went on to Kali lunyar, and the following day to Nusupan; both these villages bclong to Karang-kobar: the gradual ascent of the territory continues on the whole route, and the numerous hills are in many parts covered with a great luxuriance of vegetation: my ho anical collec ions were thercfore increas. ed every day. On the $23 \mathrm{~d}$, I proceeded to $\mathrm{Ba}$. aur, which is a separate district, at the Eastern extremicy of Karang-kobar. It is well known on account of an extensive establishment of Chinese which is formed here: 1 found a large village, more régularly laid out than those of the Javanese, inhabited chiefly by persons of that nation. The dwelling of the chief was built in the trsual stile of the Chinese, and the whole was surrominded by a rcgular stockade or wooden barrier This village, like the others dispersed solitary throngh these elevated regions 


\section{Essay, छ̈;}

has, at a distance, a peculiar appearance: all the house, are n.ked and exposed not being surrounded, and partially concealed, by clusters of Cocon-nut and other fruit trees, as in the lower tracts. The climate of Butur is conparativery cold, and the inhabitants employ and require a suitable clothing. I olscrved many of the principal Chinese to wear jack ts lined with the pr pared fleeces of sheep, which duing the morning, are very comforcable. The appearance of the inhabitants is ruddy and healthy. Eu. ropeans find the same clothing necessary which is employed during the winter in Eurepe. The Thermometer descended on the 26 th of October to $53^{\circ}$ of Fahrenheit's scale; but from the month of May to August, ic is much colder, I observed, in the houses of the Javanese inhabiting the neighbouring villages, a large space covered with heaps of ashes near the centre: several large stones serve to support the logs of wood, which are kindled here in the vight. This place like all the elevated parts of the Is. land, has a peculiar vegetation. Cocoa-nut trees, plantains, and the conmon fruit and domestic trees of the lower tracts are not found; in place of these, many European vegetables grow luxu, riantly if planted, several are spontaneous, and evidently belong to the orginal stock of the vegetables of this Isl nd; these will be pointed out in a subsequent section. A few have been accidentally introduced by seeds, mixed with the culinary seeds broughe from other countries. The vegetable productions on this Is. land form an excellent indication of the height of particular discricts. and a principal object in ny botanical remarks has been ro deteruing 
with some accuracy the geography of our indi, genous plants.

Immediately to the North of Batur is a steep hill, the Gunung Ptarangan; which has about 1000 feet perpendicular elevation above the level of the surrounding territory : to the South of this village the country is uneven, and the declivities descend chiefly in a direction from North-East to South-West, being divided by numerous ravines. Extensive tracts are covered here with plantations of Tobacco; this, with Indian-corn, is the chief object of culture: no rice is produced on account of the elevation of the tract. The Tobacco is exported chiefly to the maritime districts, and the Chinese here subsist by a smali traffic with this article, for which they bring hither various requisites from the Northern provinces.

This neighbourhood was interesting to me not only for the purpose of bringing together a general collection of many vegetables of high situations, but also in a Mineralogical point of view. A considerable range of hills rises in the north above the surrounding level: one of these has already been mentioned; they follow on the whole the direction from West ro East; several of the principal points are described in the Mineralogical section. A branch of the large volcanic chasm, which exists in the bowels of the earth, in this latitude, shews itself by several considerable outlets; a short distance west of the large Mountain Sundoro, we find the smaller ones of the Gunnng Praù, of the Pakerman and of the Roggo-sumbangan. The Palserman is situated within a few miles of Batur, and is well known in the neighbourhood, in conse, 


$$
\text { Essay, Ëc. }
$$

quence of a singular volcanic pheriomenon which occurred about 30 years ago, and will be described in the Mineralogical accoune of this districr. The Guwa-upas is dreaded by the nar tives, and according to their account, resembles the Grotto del Cano near Naples; they could not be prevailed on to conduct ine to this opening; it is situated at no great distance from the crater, which discovers itself by the discharge of volumes of smoke at intervals.

From Batur my course was eastward, inclining gently to the north, rising higher on the successive ranges of this part, and passing many of the separate points and ridges, and several very deep ravines. On the day of my departure from this village, October 27th, I halted at Konang, a small hamlet, surrounded by a circle of eminences, to the north of which rises a considerable point, well known to the natives by the name of Gunung, Diyeng, and connected with the more elevated eastern point, which at a distance receives the denomination of Gunung Praì (from its resemblance to an inverted beat or proa) although at this spoc ics numerous poincs are distinguished by separate appellations.

A traveller here does not suppose himself to be in an equinoctial regiun; he perceives the air cold during the day, and possessing at nighs a degree of keenness, which, on suddenly arriving from the lower country, is even unpleasant; no Cacoa nut or plantain trees are about the village; he fin himself surrounded by a new tribe of vegetable: he is invisorated, and capable of a degree of acrivity which appears incompatible with the nature of a hot climate, Severe bodily uxercise is not fatiguing, bus even 
desireable, and necessary to procure a pleasant temperature of the body when not warmly clorh. ed. In the foresis, the trees are enveloped with long, shaggy, depending moss, as in the coldest countries in Europe. Only a few solitary birds enliven the air; these are of a peculiar kind, and never seen in the lower regions. Natives of other parts of the Island, suffer immensely when suddenly transferred to this neighbourhooc: the half naked coolies are uniformly found in the night huddled together in groupes, and enjoying the heat and smoke of a few buruing chips.

The ançient inhabitants of this Island, of whose hrstary, religion and peculiarities all indications are now uncertain, appear to have delighted in this vicinity, as well as in similar situations at no great distance from the principal volcanoes. A Chandi, Temple or Tomb, was found near the foot of the eminence of the Diyeng, not far from a constantly smoking crater, surrounded by numerous $R e$-jos or images, most of which have been carried away or descroyed by the present inhabitants. In proceeding on my route, and commencing again the descent of the Mountain Praù, after having for severai miles followed an eastern course from the village Konane, I met and afterwards pursued along the whole declivity, one of the most scupenduus remains of the ancient inhabitants, which, in my opinion, is found on the Island. At no considerable distance from the summit of the Mountain, I obs rved a nearly regular slab, which $I$ at first mistook for a frngment of the common Basaltes of the neighbourhood, but was informed by the natives, that it was the indication of an artificial work; I very sogu met the commencement of a stair, construşs 
ed of this kind of stone, and the lava of the vicinity, r.gularly chiseled and worked into oblong plates, conduc ing, from this spot, towards that part of the foot of the Mountain on which the declivity becomes less precipitous. My estimate concerning the perpendicular height along which this stair descends brings it very near to 1500 feet : ac lower part it gradually runs off or passes into a pavement, constructed of the most regular slabs of Basaltes collected in the environs. This stair has not been preserved complete to the present period; the traces are frequenty broken or obterated, by currents of water descending with impetuosicy in accidental excavations, and the present road deviates in many places: but at intervals 3 or 4 , and somecimes 10 and more steps are found nearly entire. The breadth of the steps is three feet; the stair through the whole extent was bounded by a small margin, rising at each stde about a foot in heigh, regularly worked from the same materials.

On this descent I had an excellent opporttnity to increase my collections of the plants of high situations: I found numerotis ferns not previously noticed, and, with a large number of sorubs and trees unifor $m$ in places of the same elevation, several that were new. After a short halt at Kayu-rangkang, I proceeded to one of the principal villages of this district, denomin. ated (like the whole traet) Kali bebber. From Kayu-rangkang, the descent is very gradual: it is divided by many ravines, which transmit rivulets, and give a great degree of productiveness to the soil. The situation is still considerably elevated, and the temperature cool. I crossed again near fawar, a small Chinese 
farm, the river Serayı, descending with a rapid course from the Northern ridges.

The copiotisness of my collections on the descent of the mountain Praù made it necessary to halt several days at this place, to add the subjects to the Herbary and to complete the drawings. Kali-bebber terminates, in this part, the territory of the Native Princes, being bounded in the East by the district of Kadu: it comprizes in the North the greatest portion of the mountain Praù, extends in the West to Karangsobar and Segalo, and in the South to Ledog. It is less hilly and irregular than the districts I had previously passed, and appears to be on the whole well cultivated: but little attention is paid to the condition of the roads, and a traveller ofren finds it convenient to follow she beds of rivulets, and the mounds which separate the rice plantations.

At herteg; whither I went the 3 I st of October, I found a small village inhabiced by $\mathrm{Chi}^{-}$ nese, attached to the Farmer of the Customs; on the road I had passed the boundary between Kali-bebber and Ledog. The vicinicy of this plaee to the two large Mountains of this part of the Island, the Sundoro and Sumbing, was convenient for determining their relative situation; the road Eastward from Kerteg passes gradually into the large valley by which they are separated, rising gradually towards Redsho, sizuated on the highest part, nearly equally distane from each.

This valley has a regular, almose uniform bottom of considerable breadth, from which the territory gradually rises to each Mountain, the sides being intersected by deep ravines. 
Many of these give rise to rivers and rivulets; most of the principal streams of this part of the Island spring from these mountains; the Bogowonto and Progo flow in a Souchern direction, the begalo and Serayu follow a Western course in the central valley of the Island. The village of Re-jo is situated at the boundary of the districts of the Native Princes in this part; it has derived is name from several large stone images or re-jos, which are carefully preserved in the middle of the road in a small appropriate building, and receive tokens of veneration from the inhabitants and from occasional passengers. On leaving the broad valicy between the two mountains above mentioned, an extensive prospect opens on the traveller, exhibiting, at one view, the lower portions of the province of Kadu, consisting of an infinite number of hills. thrown together without order, and rescmbling the agitated waves of the Ocean. On entering this tract the state of cultivation rapidy in creases, in every direction large villages are indicated by immense assemblages of cocoa nut trees; and extensive plantations of Rice, indiancort, Tobacco, and almost every kind of ve etable serving for the common domestic economy and nourishment of the inhabitants, buund the prospect.

The traveller here finds his progress grearly facilitated; having traversed districts in which all conveniencies of passage are left to accident or appear to be intentionally neglected, he perceives, in the excellent condition of the roads, a care ul atcention to the means of intercourse between the various parts of this as well as O 
with the neighbouring districts: agreably to the state of the country the course of the rivers and rivulets is uniformiy rapid, and substantial bridges, in place of the temporary rafts of bambu, emploved in the districts of the Native Princes, afford a further proof of a wise administration.

Between fittis and Pakkiswing, whither I proceeded on the $2 \mathrm{~d}$ of November, the inequalities of the tract are less considerable than on the preceding route; about one mile West of the latter place I crossed the river Progo, flowing with a rapid stream from the North. The road soon approaches the Western foot of the Marbabu, and of a smaller mount called Antdong: beyond the basin of the river Ello it gradually ascends, and traversing numerous ravines, reaches the more elevated declivities towards the top of the Marbabu; it here passes successively the villages of Kamantran and Koppeng, and consequently descends again through many intervening vallies to the Eastern fooc. Leaving the usual route from Koppeng to Salatiga, I went on directly East, and met the high-road, leading from Sumarang to the Capitals of the Native Priuces, at Kali-Gandu. In the afternoon of the 4 th of November 1 seturned to Souracarta. 


\section{POSTSCRIPT.}

List of proper names from the first Section of the Essay.

It is to be observed that the sound emplayed by the Javanese, in expressing the letters, has been followed as nearly as possible, viz.

Javanese

$\mathrm{Ho}$,

No

Cho (or Tsho)

Ro

Ko

Do

To

So

Wo

Lo

Po
Euglisiz

H

N

$\mathrm{Cl}$

R

$\mathrm{K}$

D

$\mathrm{T}$

S

W

L

$\mathrm{P}$

Ddo, has a peculiar sound, resembling a double $d$, which can only be properly expressed by a native: it is indicated by $d d$.

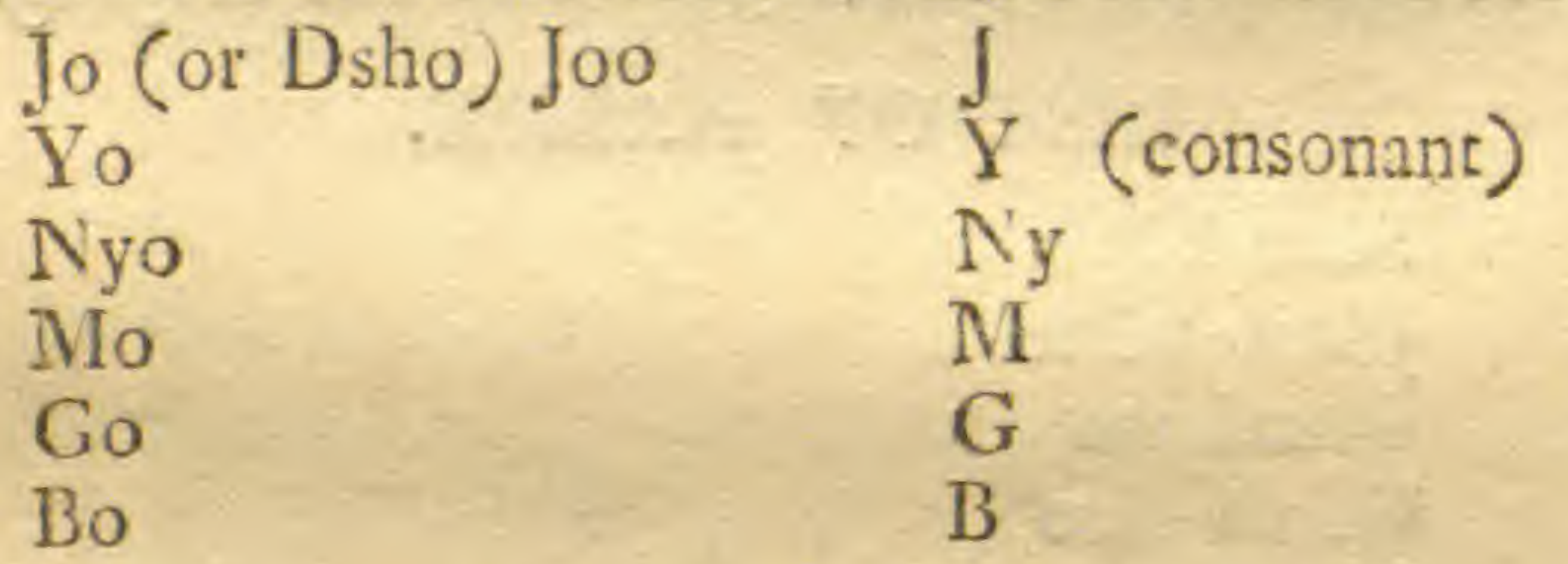

Tto, answers to the double $d$, and can only be expressed by a native; is may be indicated by $t$.

$\mathrm{N}$ ro

$\mathrm{Ng}$ 
The vowels are uniformly sounded as follows:

a broad, as in hall

e (as a in common) as in het

$i$ (as ee commonly) as in field

$a$ as in note

u broad, as in blue

The syllable which has a long protracted accent is marked with-as in Weddí; indicares a very short enunciation, to throw the accent with more force, on the other syllable. This sign' simply denotes the accented syllable, as Kérto; $\mathrm{C}$ is never employed alone, $\mathrm{ns}$, in the numerous words where $e$ follows, it would be undetermined whether to pronounce it hard or soft.
Kemadu
Kemiri
(Cemadu)
Keji
(Cemiri)
(Ceji, \&c.)

Kendal, \&c. \&c. written with $C$, mighe be pronounced Semadu, Semiri, \&c. K is sufficent for every purpose, not liable to mistake, and more consistent with the genius of the langunge,

\section{LIST OF NAMES,}

Sûro-kérto

Jókjo-kérto

Mlattâram

Kérto sûro

Marâpi

Marbâbu

Manching-an

Kâdí-langu

Bûbutan

Jónno 


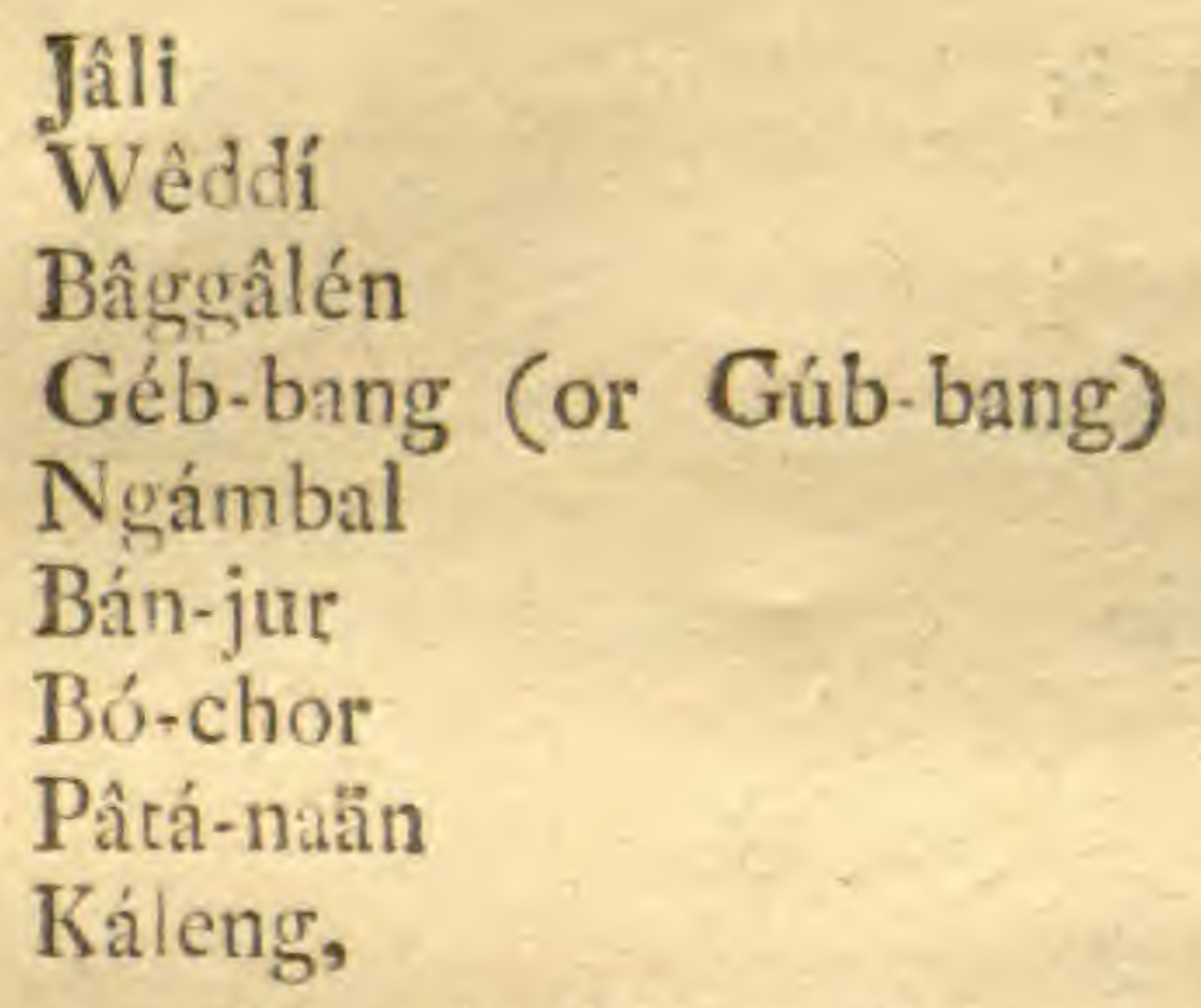

Note. - The $e$ in this, and in many other words, has a sound which most resembles the English $u$, as in us, ugly, \&c. being obcuse, and intermediate between 0 and $u$ : it is expressed or indicated by a particular mark, called pepist; in this manner by the Javanese, and something similar must therefore be adopted to express it. Kaleng might be written Kálêng, Kalêng, or Kalûng. It is one of the most common and familiar native vowels, and occurs incessantly in their language, as $S e \hat{g} \dot{e}$ or $S t i g g o ́$, boiled Rice-Nassi of the Malays. Assüm, Tamarind, Assam of the Malays. Bádúg, a fermented liquor, \&c. \&c.
Wêttón
Chí-chíng-gôleng
Kâ-chang
Pág-ge-láran
Jíngkla
jêtcís or Júttís
Aya
Pring túttul
Rômo
Jâti-nogóro
Selon-dókko
Dòplang 
Bányu-más

Sêráyu

Káli-wêddí

I êdâ-gángan

Ma-ös

Adi-póllo

$\Lambda$ di-ridjo (ri-jo)

Adi-ród-jo (ro-jo)

Tâlá-chap

Chéribon

Nûso-brámbang

Nûso-kombángän

Malákka

Suka-pûra

Segóro-ânakan

Dayu-lúbur

Jùrug-leggi (or lûggi)

Suko-ród-o or ró-jo

Púrwo-kérto

A-ji-bárang

Tiád-jum

Kâbung

Dâto: r

Prôbo-ling-go

Gûnung-gêd-dì

Kumùtuk

Puwása

Bán-jar

Pùrwo-re-jo

Gomûru

Merâwu

Kùtto-waringin

Sundóro

Sùmbing

Pawi-nian

Lâwet 


\section{Essay, E'c.}

Karang-kóbar

Pùs-ger-pélla

Kâli-lúnyar

hàtur

P aráng-an

Rôgô-jambángan

Guwo-upas

Gunung-di-yeng

Chándi

Ré-jo

Ledóg

Kêrtés

Bêcálo

Kadú, better Kêddú

(N. B - I am uncertain whether it is not written Cidd-dil by the natives, it is often thus pronounced.)

Pakis-wíring

Andong

Ello

Kamántran

Kóppeng

Kuli-gándu. 


\section{SECTION II.}

\section{Concise Geographical Sketch.}

The Western Division of the territory of the Native Princes consisrs principally of

Mattaram (the Western portion)

Baggalen

Banyu-mas

Romo

Dayu-luhur

Merden

Lurung-tenga, Kerto-negoro, and several inconsiderable tracts.

Segalo

Karang-kolar

Ledog

Kali-bebber and

Gowong

A. In the Western portion of Mattaram, West of the Capital of Jokjokarta, the principal villages near the high-road, which are marked on the map with the corresponding numbers, are, (See the Index annexed)

Bantul

Bantul-karang

Bazar Tagal-layang

Brossot

Pacrallan

Kademangan

Krettek

Karang-wuni

Kachubung-darat. 
Kadilangu is situated on the Eastern banks of the river Bogo-wonto, which forms the bounda. ry between the Mattaram and Baggalén. The largest river in Mattaram is the Progo, the principal branches of which will be mentioned in the next Section: it receives, near Brossot, a small branch from the West called Galur.

The numerous hills which compose the IVestern part of Mataram are not comprized within the limits of this sketch; many scparate ranges appear to descend from the Mountains Sumbing and Koripan, directing the course of the rivers of Progo and Bogo-wonto.

B. The province of Baggalén, not only in point of extent, but particularly in regard to the state of culture and population, is one of the principal districts under the administration of the Nacive Princes: alchough it contains no capical with an excessive population, a large number of considerable villages are scattered over its whole cxtent: these are in greatest proportion appropriated to the domestic services of the Princes, the "Gladak"-and are administered by a Tommo.gg-gong from Sourakarta and from Jokjokarta. As it would swell the catalogue unneccssarily, I shall only enumerate the principal villages on the great Southcrn route to Karang-bollong, those on the route which I followed, and several of the principal sub-divisions, which have hitherto not been pointed out in the geographical sketches or the nups.

I. Villages on the Southern Road. Wonno-rotto

Ngawu-awu 


\section{Tegges \\ Wollo \\ Wawar \\ Rowo \\ Telogo \\ Blengor \\ Benner \\ Ngambal \\ Banyar \\ Botshor \\ Perchuritan \\ Bedati \\ Patanaan \\ Kaleng \\ Wetton \\ Trunting \\ Klegen \\ Mungu}

q. Villages dispersed through the centrat portions of Baggalen.

Jonno

Weddi, - two considerable Bazars which have been mentioned above.

Bubutan, a small Bazar.

Jenner, disto.

Gebbang

Suren

Banyu-urib

Poppok

Punda

Brengkol

Plumbon

Gadungan

Lajir

Gessian 


\section{Essay, Eेc.}

Kwangun

Tanjung

Pengilong

3. a. Near the Norhern boundary, and $b$, the Wcstern excremity of this province, are to be noted.

a. Samawung, a considerable village, the residence of the Tommong-gong from Jokjokarta.

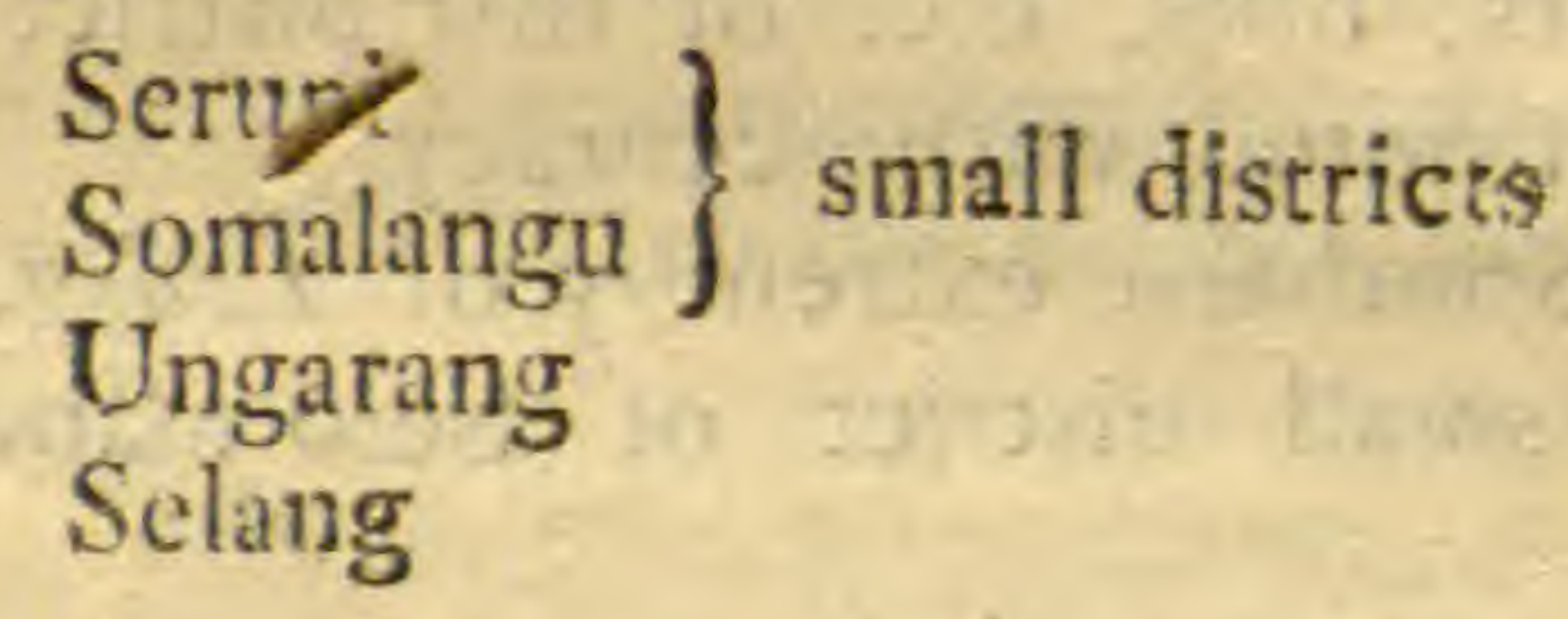

b. Rangka, a small district, containing numerous villages

$\left.\begin{array}{l}\text { Kutto-vinangon } \\ \text { Jerakka }\end{array}\right\}$ large villages

Most of these small tracts and villages (of the 3 d divison) approach or are situated on the declivitics of the central ranges, from which numerous rivulers and rivers have their origin. Bogo-wonto, the chief of Baggalen, has alscady been mentioned: Lerreng arises towards the Nestern extremity, flows through the centre of Baggalen, and receives the rivers.

\section{a. $7 a i t$}

b. Gobbang, and several others.

The ather rivulets arising near the Western extremity of this province take a Western direccion, and unice to the river Chiching-goleng; a considerable stream, which follows the direçtion of the ranges of Karing-bollong. 
The Southern portion of Baygalen is low and level; the Northern gradually rises towards the central ranges, but comprizes no Mountain of any importance; the particular denominations of the hills composing these ranges have not been as yct accurately ascertained: along the Northern boundary of this province, commencing in the East; we find the following districes:

1. Gowong, consisting chiefly of the Southern declivities of the Mountain sumbing. (The villages, rivers, hills, \&c. of this district have. not yet been noted with accuracy.

2. The Southern extremiry of Ledng. Kali-wiro.

3. The small district of Selo-manek or

4. Segalo (which will be mentioned below.)

5. The ristrict of Panjer (one of the subdivisions of Banyu-mas, to be mentioned in the sequel. )

6. The district of Romo.

c. Romo is a considerable tract which has the same constitution as Baggalen: in the East, the North and West it is bounded by the hilly tracts of Banyu-mas, in the South by Rangka (one of the smaller sub-divisions of Baggalen) several considerable points of the central ranges occupy its Northern ports; its rivers and rivuluts descend uniformly to the Chiching-goleng. Among many villnges which are dispersed through this tract I shall only notice Fati. nogoro, the principal, and residence of a Tommong-gong who administers here on behalf of the Sultan, -and Kranjingan, a Chinese farm; both are marked on the map. 
d. Between the river of Chiching-goleng in the East, and that of Aya (one of the sub-diyisions of Banyu mas) in the West, several succossive ranges of hills are found, which have a direction from North to South, and, projecting considerably beyond the general stretch of the Southem coast, form a peninsula, which, from the chief village of the neighbourhood, has been denominated the Peninsula of Karang-bollong. In ancient times this formed a part of the province of Banyu-mas; is has been mentioned above; and since the regulat administration of the caverns in which the Edible-Bird's-Nests are found, has been considered as a separate district. The general appearance of this peninsula will be described in the succeding section. The chief villages are-

Karang-bollong

Poris near the bay of Passir

Jeladri Guntur
Karang-mangu three hamlets at the mouth of Suwit Chiching-golçng.

Jumennar Karang-Selo

Nagassari and on the route towards Aya. Jinkla

The principal caverns in which the Biru's Nests are at present collccted are:

Guwo-Dahar

Guwo-Geddé

Guwo-Nagassari, and

Guwo-Jingkla.

Of the numerous points which rise more pre. cipitously from the ridges compasing this pe- 
ninsula, the denomination of few is uniform and determinate among the natives: Karang-kuda has been pointed out on the map-at the termination of the Eastern ridge a cavern is found from which the settlement has derived the name of Kar rang-bollong.

The rivulets arising from these ridges unite to the Chiching-goleng in the East, and to the river of Aya in the West.

The province of Banyu mas occupies a very considerable portion of the territory of the Native Princes; it is bounded by the district of Segalo in the East, and by several of the sub. divisions of the district of Cheribon in the West, strecching transversely from the southern Ocean to the declivities of the Mountain of Tagal. It is composed of the following subdivisions, viz.

a. Aya

b. Panjer

c. Passir

d. Probolingo, and

e. Banjar

exclusive of the environs of the capital. Ays commences at the peninsula of Karang-bollong in the East, and extends in the West to the river of Juruk-leggi, which discharges itself beyond the Eastern boundary of the Island NusoBrambang, occupying a length of coast of nearly thircy miles, its breadth is also considerable; the Northern portions comprize the declivities of the central ridges; near the shore it is low and marshy.

Its principal villages and settlements are neat the southern Ocean, between the discharge of the river Serayu and the hill Bedagangan - here an 
extensive tract is in a state of culture. The principal villages are:

Adipollo

Adiryo

Adirojo

Sawangan

Bunton

Karang-pandan

Winong.

To the Eastward of the hill Bedagangan only solitary villages are found dispersed through an extensive tract, the greatest portion of which is a marsh, or an inaccessible wilderness; those which deserve notice are:

Widoro-pajung

Jittis

Aya, and

Doplang.

On the route from the capital to this district we note

Wono-seppi

Maos

Kali-weddi

and various smaller villages dispersed through the neighbourhood; and

Penggalan

Towards the boundary of Romo we note: Selondoko, and, near the Western extremity, the sectlement (at the boundary of Cheribon) Talachap, with the adjoining small tracts of Donan

Jojok and

Juruk leggi

which have severally been nieutioned in the Journal. 
b.) Panjer, the second sub-division of Banyu-mas, is somewhat removed to the Eastward from the other districts of which this province is composed: the district of Romo, which bounds it in the Wcst, is as it were intruded between Panjer and Aya. The Southern pare of Panjer is level and in a high state of cultivation; it is here bounded by the Baggalen. In the North it is hilly, and, like the other tracts on the central ranges, contains only a scanty popution.

Kabumen is one of the most considerable villages of this district.

c.) Passir is the most-westerly of the divisions of Banyu-mas, and extends to Dayu-luhur and several tracts belonging to the Residency of Cheribon: in the North it is bounded by Lossari and Tagal, in the South by Aya, and in the East it is united to the following sub-division of this province: the Southern and Eastern portions have a gradually inclining situation, and are chiefly in a state of culcivation. In the West and North it is hilly, the culture and pepulation is not considerable.

Suko-rojo and

Purwo-kerto

are two very considcrable villages, at each of which a native chief Behi) resides, who is subordinate to the Tommong-gong who administers the province.

Aji.barang is a small tract near the western, and Kumutuk near the northern boundary of Passir; through all these numerous villages are dispersed, but only the principal haye been noted on the map. 


\section{Essay, Ẽc.}

d.) Probolinge, the fourth sub division of Banyu-mas, has the same tocal constitution, and a similar state of cultrvation; it is bounded in the north by Bobotsari, Kerto-negoro and Jianna, in the east by Banjer, and in the south, by that part of this province which is annexed to the environs of the capital. Its villages are very numerous. Probolingo, the chief, has alone been noted on the map.

e.) Banjar, the last sub-division of this province, is the most easterly in its situation; its form is on the whole oblong, and it stretches far fi om west to east. Its constitution is more diversified than that of Passir or Probolingo-it is, on the whole, uneven or mountainous, bur many of its uneven districts are in a high state of cultivation: they are covered with a fertile soil and are well watered.

Banjar is bounded in the west by Probos lingo, in the north by the Honorable Company's maritime districts Pamalang, Pakalongan, \&c. in the east by Karang-kobar and Segalo, and in the south by Panjer and Merden. Among jts numerous villages I shall only point out Banjar (the chief)

\section{Winorong \\ Gomuru \\ Kutto-Waringin, and Gunung-Raja}

Besides the five districts above enumerated, the tevenue of which is claimed almost exclusively by the Sovereign, a considerable portion is ap propriated for the private revenue of the Tommong-gong, who administers the province- - It 
comprizes the environs of the capital, a large village also denominated isanyumas, and a long norrow tract extending on both sides of the river Serayt, towar's the smalf tract of Lurung teng $a$ or Kali-mendong, which is here intruded between the divisions of Banyu-mas.

Besides the capital, where the Tommonggong resides, are clitefly to be noted the villages

Sama-gedé

Gomellera, and

Purwo rejo.

Among the Mountains and Hills of this province, the Mountain of Tagal, denominated by the natives Gustung-Gede, or the large Mountam, and various branches of the central ranges, extending longitudinally through the whole of this division of the Island, deserve particular notice. The Mountain of Tagal stands at the boundary of this and the northern districts already mentioned, and its declivities con. sticure chiefly the sub-divisions of Passir and Protolingo: the central ranges are on the whole arrenged in two divisions, one on the north, the other on the sotth side of the river Scrayu, each consisting of numerous smaller links, which are often disposed in succession and nearly parallel to each other. Besides this several ridges (arising near the western declivities of the Mountain of Tagal) extend through Aji-barang, Daym-luhur, \&e. towards the sonthern shore, meesing and uniting with the terrination of the central ranges, which, to the west of the capital of Banyu-mas, also incline suddenly towards the souch. 
The names of all the separate points which were ascertained with accuracy are mentioned in the next Section, to which I therefore refer at present.

It may be proper, in this place, to enumerate in succession, the principal rivers of this part of the Island; several of these have already been mentioned ; and, with few exceptions, they arise in, or pass through a part of the province of Banyu-mas. The river Progo alone, is encirely distant: the river Bogo-wonto (forming the boundary between Mataram and Baggalen) receives a principal branch of the river Lerreng, which arises near the Western boundary of the district Panjer. Several of the principal branches of the river Chiching-goleng arise from Panjer, and from the Eastern extremicy of Aya. The River of Aya receives its sources from various branches, exclusively from the province of Banyti-mas; their direction is pointed out on the map; the branches from Pring-tuttul, Selondoko and Cheleman are the chief; they inite in the lower part of the district of Aya, and then follow the direction of the ranges of Karrang-bollong to their discharge into the Ocean, Another principal river of the tract of Aya flows into the Ocean at the Westem foot of the hil! Bedagangan: it is called the river of Alitirojo, and has two principal branches, one from Doplong, another from Kaliwedei, which receive many small ri ulets from the Northern hills of Aya, and contribute to innudate this tract.

Following the coast to the IVestward, we meet, about five milss from Adi-rojo, the outlet - the river Serayu; this is one of the lorgest 
streams of this Island; its source is neal the North-western de clivities of the Mountain Sundoro, from the hill Jajar (inclining to the Northern parts of the Mountain Praul) its course is first from North to South, having passed the districts of Kali bebber, Ledoy and Segalo, it enters the province of Banyu mas, through which it flows to the Ocean. Soon after arriving in Ledog it turns to the Westward, and continues in this direction till beyond the capical, and then inclines South to its discharge. It follows, on the whole, the direc ion of the large central valley in this part of the Island, which is confined in the North and South by the ranges of the central hills above mentioned. The Eastern branches will be mentioned in the sequel; soon after its arrival in this province, it receives the Merawu, a large river from the North, and subsequently the rivulets of
Blimbing
Mendong
Sapi
Deris, and
Piosso, from the South.

In this part of its course no considerable branch enters from the North, till the river of Klawing, which unites to it near Soma-gedé, carrying down the waters of num rous streams from the Northern ranges, and from the mountain of Tagal. Besides various other branches the river Klawing receives the

\author{
Gintung \\ Kelahan \\ Tambra \\ Pekachangan,
}


and, near its union with the Serayu, the River Pellus, which traverses the Eastern parts of Passir, and receives many subordinate streams, among others the

\section{Bellud \\ Bakkal \\ Benner, and \\ Lagur.}

Another large branch from the North unites the various rivers and rivulers of the central portion of Passir, which, as well as those flowing into the river Pellus, have their source from the declivities of the mountain of Tagal; it is called Lo-gowok, a principal branch is the river Banjaran, nearly of equal size; boch receive numerous rivulets in the higher districts, of which the names were not ascertained wich accuracy. The Lo gowok falls into the Serayu, several miles West of the Capital.

The Western declivities of the mountain of Tagal, and the adjuining central Ranges in that direction, furnish three rivers which unite sourhward of Aji-barang: The Datar flows near the principal village of that District, the Kawung a few miles Westward, and still furcher in the same direction the Tiarum; the two former having uniced to the latter, it subsequently takesan Eastern direction, and meets the Scrayu several miles to the South-West of the discharge of the river Lo-gowok.

Very near the mouth of the Serayu, it receives from the Wese a large branch, of nodist tunt source, conveying the waters of the lower marshy districts, which accumulate at the Southern declivitiss of the central runges: it is 
denominated Bengawang Brondong, being broad and admitting the tide to a considerable distance.

Very near the Western boundary of this proyince we find the river Juruk leggi, which near its discharge resembles the Bengawang Brondong: it receives various branches from? the districts of Dayu luhur and Cheribon.

f.) The district of Dayu-luhur is situated at the Western extremicy of Banyu-mas, being bounded in the North Hrebes, and in the West by several of the sub-divisions of the Regency of Cheribon; in the South it is uniced to the tract called Feruk-leggi: from the information of the natives at Aji barang, the greatest portion of it is in a state of wilderness, and many of the inh bitanis of the Southern extremity have been carried off by the pirates, in former years, or have removed to situntions of more security in Cheribon and Banyu mas.

At the Eastern extremity the province of Banyu-mas is united to Karang-kobar, Segalo and to the Northern portion of Baggalen: this parts of the I sland is troughout a succession of hills and mountains, having on the whole a longitudinal direction, as far as regards the coasts.

g.) Segalo occupies thetracts on the North and the Souch side of the river of Serayu, rising in each direction by successive ascents and ridges towards Karang-kobar in the North, and the Northern ranges of Baggalen in the South; the face of the territory is very uneven, and the inequality is increased by the numerous rivulets poured into the Serayu from the ridges on each side. Its villages are numerous, only the fo! 
Fowing are noted on the Map-Segalo (the principal) and

Sawangan.

h.) Karang-kobar has on the whole the same constitution as Segalo, but rises more precipitously towards the Northern ranges; these are enumerated and described in the succeeding section, as well as the principal hills near the common route from Banjar to the north. Here the principal villages are

Telogo

Pagger-pella

Karang-kobar (the chif village)

Kali lunyar, and

Panusupan.

The small tract of Batur, situated on the declivitics of the Northern ranges, intervenes here between Narang-kobar and the following district.

i.) Kali bebber commences at the summit of the Gunung-prow in the North, and stretches to the district of Ledog in the South: in the West it is bounded by Karang-kobar and Segalo, in the East by the Kadu. It is composed, in the North, of the declivities of the mountains Prow and Wismo, and in the East of those of the Sundoro: its central tracts have an unequal constitution, rising and descending like the waves of the Sea. The village Konong is situated near the declivitics of the mountain Diyeng, and at considerable elevation on the mountain Prow; near the foo of the latter we meet Kayurangkang and Menjer; furcher to the south Blederan, Jawar, Kalibebber and numeross 
others. More cxtensive than the last is the district of

j.) Ledog, stretching from the declivities of the Sundoro and Sumbing, to the cencral ranges of Baggalen and Gowong; in the IVest is is bounded by Segalo, and in the East by the Kadu. The face of the country resemtles on the whole tha: of Segalo, but its ridges are less elevated and reoular. Its principal villages are Ledog and Balle-kambang: besides these are to be noted Selo-merto

Do-merro

Selo-Kromn

Krossak and Gunttng Tawong

Kerteg

Gondong

Banyu-smurub, and

Rejo.

k.) The discrict of Selo-manek or Kali-wire was formerly united to Lebog, but was separated frow it by one of the former Sultans of Jokjokarta: it is not considerable in extent or populacion.

All the rivers from these various districts flow towards the central valley, and unite to the Serayu. In the Karang-kobar discrict the chief river is the Merawth, already mentioned ahove, which rises near Batur from one of the highest points of the central ranges; it receives the ali-urang (a considerable stream from monnt Rorgo-Jambangan) the Telotto-surent and $P$ a uraban, which are marked on the map.

The water from the more eastern points of the central ranges unite to the river Tulis, two branches of which, the Kali-puti and Dolog, arise from the hill Pakerman, 
The eastern points of the central ranges, and the declivities of the mountain Sundoro, in the district of Kali-bebber, supply the first sources of the river Serayu, which here receives, besides the river Tulis, various other rivulets from the declivities of the Sundoro and Sumbing. The riwer Segalo arises from the southern and western foot of the Sumbing; having received the river Gung, and many others from all directions, its course is west inclining to the north: it is now ncarly equal to the Serayu in size, and both streams unite at Selo-kromo.

The mountains of Sundoro and Sumbing form the boundary, in this part, between the districts of the native Princes, Kali-bebber and Ledog, in the west, and those of the Hon. Company, the Kadu, \&c. in the cast. They will be mentioned in the next section, as well as the other hills and mountains of the western districts.

As the plan originally proposed has only embraced a very concise geographical sketch of the territory of the native Princes, I shall, in prosecuting the further route, enumerate only several of the principal villages (whose siturtion is marked on the map) and point out the northern branches of the river Progo, whose discharge is in the first district abovementioned.

On leaving the declivity between the two mountairs Sundoro and Sumbing, near the boundary of the Kadu, we meet

Kleclung

Telahab

Baponan 
Jittis

Parakkan

Selo-korung

Geddu-siwur

Pakkis-wiring

Sechang

Bazal-grabag

Kamantrang

$\left.\begin{array}{l}\text { Ngablak } \\ \text { k opping }\end{array}\right\}$ under the Residency of Samarany Kali-gandu, on the large road from Salntiga to Souracarta.

The river of Progo consists of two principal branches: the western receives this denomination from its source; the eastern is called the Ello. The former arises near the mountain Ungarang and the rangen west of it: it receives the river Gale from the monntain Sundoro and the Sarangan, Fampirosso and Lungi from the declivities of the Sumbing, besides unmerous orher rivulets from east and west. The river Ello rises considerably eastward, likewise from the declivities of the mountain Ungarang, and receives two large branches from the mountain Marbabu, the Daru and Bollong: its course is for many miles parallel to that of the Proge, and after receiving several streans from the Marbabu and Marapi, it winds somewhat abruptly to the west and unites to the Prozo, in a direction nearly south-west of Migellan, the capital of the Kadu. 


\section{Essay, Eंc.}

\section{GEOGRAPHICAL INDEX}

To the Numbers Marked on the Mineralogical Shetch.

No. 1 Bantul

2 Bantul-karang

3 Bazar Tagal-layang

4 River Progo

5 Brossot

6 Rivulet Galur

7 Patallan

8 District-Kachubung

9 Kade-mangan

10 Kachubung darat

11 Krettek

12 Karang-wpuni

${ }_{13} 3$ Kadilangu

14 River Bogowonto.

15 Bubutan

16 Bazar Jenner

17 Jonno

18 River Jali

19 Gebbang

20 Semawung

21 Weddi

22 Somolangu

23 River Lerreng
24 Kutto-winangon

25 Selang

26 Wonno-Rotto

27 Ngawu-awu

28 Tegges

29 Wollo

30 Wawar

31 Rowo

$3^{2}$ Telogo

33 Blenyor

34 Benner

35 Ngambal

36 Banyur

37 tochor

38 Perchuritan

39 Bedati

40 Patanaan

4.1 Kaleng

42 Wetton

43 Truntung

44 Klegen

45 Mungu

46 Guntur

47 Barang-mango

48 Suwu

49 River Chichinggoleng 
50 Villiage Ka- 80 Rivulet Lebbeng rang.bollong $\quad 81$ Hill-Chelenan

51 Karang-bolong 82 Banyu mas

52 Guwo-Dahar

53 Guwo Gedè

${ }_{3} 3$ Rivulet Banyumas

54. Bay of Passir

55 Wollo

84 Hill Womno-

56 Poris

57 Hill Karang. kuda

$5^{8}$ Jeladri

59 Nagasari

60 Guwo-Nagasari Seppi

85 Hill Kali-weddi

86 Kali-weddi

6t Village Jingkla 91 River Serayu

62 Guwo Jingkla 92 Peng-gallan

63 Village Aya

93 Adipollo

64 River of Aya

65 Jettis

66 Widoro-Pajung

94 Adiryo

95 Village Adirojo

67 Pring-Tuttul

68 Jerakka

y6 River $\Lambda$ dirojo

69 Adipollo

70 District of

97 Hill Bedagangan

98 Selok

99 Sawangan Rangka

71 Rogo-Donno

100 Buiton

101 Karang-Pandan

72 Rivulet Plemaw 103 Bangawang-brongan

73 Jati-Nogoro dong

104 Plerenan

74 District of Ro- 105 Donan 1110

75 District of Pan-

106 River of Jurukjer

76 Kabunien

77 Rivulet Jju

78 Kranjingan

79 Selondokko Leggi

107 Talachap

108 Jojok

109 Banjar

110 Karang Pachi

1 II Ujung-agung 
II Brambang

1 I 3 Karang-Bolo

114 Juruk-1 eggi

115 Uill Pellem

116 District of $\Lambda$ ya

1 if Rivulet Bignr

1 I 8 Suko-Rojo

1 19 River Pellus

120 Rivulet Bakkal

121 Rivulet Benner

122 Purwo Kerto

123 River Banjaran

124. Village Karangluwas

125 RiverLo-Gowok

126 River Datar

127 Aji-barang

128 River Kabung

$\left.\begin{array}{l}129 \\ 329\end{array}\right\}$ River Tiajum

130 Passaran

131 Petuguran

I 32 Windu-aji

133 Kali-erang

134 Galu-timor

135 Mount Tagal

${ }^{1} 36$ Disuict of Kemutuk

I 37 Karang-anyar

138 River Bellod

139 Diserict of Passir 170 Hill Lawet

140 District of Pro- 17 I Gunung Raja bolingo

$\checkmark 41$ Rivuler Kelagan

172 River Urang

14.4 River Gintung

145 Kerto-Negoro

146 Bobotsari

147 Jionna

148 Bechi

149 Sama-gedé

${ }^{1} 5^{\circ}$ Rivulet Piosso

I5 I Rivulet Deres

152. Gemellem

${ }_{153}$ Risulet Sapi

154 Purwo-rejo

155 Rantar

I56 Mendiraja or Lurung-tenga

157 Rivulet Men. dong

158 Discrict Merden

159 Rivulet Blimbing

160 Winorong

161 District of Banjar

162 Gemuru

163 Kutto-waringin

164 Legok

I 65 Cheng gawur

166 Banjar

167 River Merawu

I 68 Rivulet Winong

I 69 Moune Pawinian

142 River Kelawing I 74 Paggerpella

143 Probolingo

I 75 Hill Teloge-leli 
I 76 Hill Sari

177 Rivulet Telottosuren

178 Hill Akkar

I 79 Hill Pening-galan

180 Moune Roggojambangan

18 I Karang-Kobar

182 Hill Krangeang

I 83 Hill Gaja

184 Rivulet Panaraban

I 85 Kali-lunyar

186 Hill Lumbung

187 Districe of Kiarang-Lobar

158 anusupan

18 g Hill Teki

190 Batur

191 Hill Prarangan

192 Hill Pengangguingan

193 Wora-wari

$19+$ Hill Butak

195 Hill Pakerman

196 Crater

197 Guwo-upas

I98 Village Kassirian

199 Village Jampang 200 River Dolog 20 I Rivulet Puti 202 Hill Malang 203 Hill Nagasari 204 River Tulis 205 Mount Wismo 206 Hill Koppok
207 Hill WagerTipis

20 Konang

209 Mount Diyeng

210 Mr. Telogo-Jebong or Prow

2 i I Telogo-Menjer

212 Menjer

2 I3 Kayu-Rangkang

214 District of Kalibebber

215 Blederan

216 Jawar

217 Chepokko

218 Kali-Bebber

219 Rivulet Ireng

220 Rivulet Prupuk

22 I Mountain Sundoro

222 Hill Kombang

223 Hill Arom

224 Hill Jajar

225 Hill Ǩendil

226 Rivulet Tumbelan

227 Rivalet Chechup

228 Limbangan

Rivulet Jappar

230 Rivulet Prumpung

231 Kerteg

$23^{2}$ District of Ledog

233 District of Segalo

234 Segalo

235 Kendeng Besser

236 Sawangan 
237 Selo-Kromo

$23^{8}$ Krassak

239 Gunung-Tawong

240 River Bogalu $26_{5}$ River Lungi

54 I District of Sclo- 266 River Progo manek or Kali-267 Pakkis-wiring wiro 263 Rivulet Murug

242 Mountain Da- 269 Sechang makyu or Kori- 270 River Ello pon 271 River Daru

243 Ungarang

244 River Gung

245 Rivulet Simo

246 Gondang

\$47 Rivulet JurangJuruk

248 Banyu Smurub

$2+9$ Rivules Buto

250 Rejo

251 Kledung

252. Mountain Sum bing

253 District of Gow. ong

254. Telahab

255 River Gale

256 Paponan

257 Jittis

258 Tersono

259 Districe of Kadu

260 Parakkan

261 Rivulet Parangan

262 Selo-Karung
263 Geddu-Siwur

$26+$ Rivulet Jampirosso

272 Bazar Grabag

273 Mountain Ungarang

274 Hill Gaja

275 Hill Telomoyo

${ }_{27} 6$ Hill Andong

277 Mountain Marbabu

278 Mountain Marapi

279 Komancran

2 so Ngablak

281 Koppeng

282 River Bollongs

$28_{3}$ Salatiga

$28+$ Kali gandu

285 Ampel

286 Buyulali

287 Magellan

288 Bojong

289 Semen

290 Jokjokarta

291 Selo Merto

292 Balle-Kambang. 


\section{SECTION III.}

\section{Mineralogical Remarks.}

The following remarks are in immediate connection with the Essay on the Mineralogy of the Western parts of this Island, contained in a preceding part of this volume. Since this was written several years have elapsed: it was my original intention to continue, without interruption, the Minernlogical Essay to the Eastern extremity; this intention has necessarily been changed, but a favourable opportunity has occurred of examining more minutely several districts, which are comprehended within the limits of the first part of the mineralogical description, and as I have been enabled to extend my, remarks on various points, it has appeared desirable that the former omissions should be supplied, and that several errors should be rectified.

On the tract from Souracarta to the Southern declivities of the mountain Sumbing, I suspend all remarks at present, as I have decermined to make it an object of careful investigation.

From Jokjokarta to the penirisula of Karangbollong, the tract, in a direction directly West from the capital, is low, and bounded in the North by the central ranges of hills, which are observed at intervals from the large road, which follows nearly the direction of the shore. Not far from this capital several eminences are scattered in a Western direction, the nearest of which, being completely calcareous, is denominated lime hill, or Gunung-gamping by the natives, as it supplies the whole neigbourhood 
with this article; between Brossot and Kadilangu several hills descend towards the South, but the principal central ridges preserve a distance, varying from 10 to 15 miles, from the shore. The sorl which covers this low tract is a mix ure of clay and sand in various proportions; near the central range it consists chiefly of the former, and along the shor e of the latter. Through the whole extent the shore is bounded by one or more ranges of low sand hills. From the river Bogo-wonto to the peninsula of Karang bollong, this tract is annuolly inundated during the rainy season, by the waters brought down from the central ranges by the various branches of the rivers above mentioned, in the Geographical description. 'The intercourse between the different villages is now carried on chiefly by means of canoes or small boats; in the vicinity of shore the traveller passes conveniently over the more elevated sand hills; as the waters retire, the culcure of rice is commenced, and most parts afford but a single annual crop. I have attempted to shew on the Map, the points at which the projections from the central ranges descend most towards the shore, and those which afford the broadest plain for cultivation. Only in few situations solitary fragments of Basaltes are observed, with rounded angles; the places where I passed the rivers of Progo and Bogowonto were at a considerable distance from the central ranges, but the beds were filled with volcanic stones carried down by the streamst.

Some peculiarities of the hills which compose the peninsula of Karang - bollong have already been mentioned in the journal: their direction is 
from North to South, they terminate precipitousIy at the Ocean, and contain numerous perpen. dicular caverns. Having crossed the river of Chiching-goleng, the traveller meets at once the substance which forms the prineipal basis of these ridges; it is an aggregate rock, in its nature approaching most to that kind which is denominated by DeSassure Poudingue-Puddingstone-composed of fragments of various sizes, from very minute particles or grains of sand, to such as have six or more inches in diameter. They adhere very closely, but without any intervening cemen, in which they differ from the Amygdaloids of Werner, or from Porphyry to which, in other respects, they have great affinity. The constitution of this rock, one of the most common substances which forms the basis of the Island, is greatly diversified, and the following remarks apply only to the rock which composes this peninsula. It is found in some parts of the Island of a degree of compaceness sufficient to enable it to take a polish and exhibits in other parts all the varieties of Vol. canic or of Basaltie Tufa.

In the separate particles composing the aggregate rock in the ridges of Karang-bollong many of the varieties of Tolcanic stone which are found on the Island, can be discoverd. The most universal is basaltes of various form, colour, size and composition; next to this are Lavas; some are made up chiefly of pumice, quartz and schorl, some can scarcely be distinguished from sand stone, in others numerous minute particls of schorl are bedded in white sand, which is agglucinated by means of a very pure whice clay 
in a state of partial decomposition. Green-stone, Hornblende and Osidian are also observed.

The external surface of this rock, especially where it is exposed to the action of water, is also greatly diversified, and often exhibits very grotesque figures: the minute particles of sand, \&c. having gradually been carricd away, the large fragments, projecting, form a very uneven surface. From the foot of the hill, at the common place of passing the Chiching-goleng, I traced it to the discharge of this river; here immense masses are heaped together, covering an extensive tract. At the termination of the hill several caves exist, and in one part a vault completely penetrates an extremity of one of the particular ridges. This is denominated Karangbollong literally "hollow rock" and has given the name to the whole settlement. The vault here is very explanatory of the constitution of *the caverns in which the Edible Bird's-Nests are formed; on the whole it agrees with the rocks above described, but many of the separate fragments are of considerable size, exceding 6 or 8 inches in diameter : the largest of these are $\mathrm{Ba}$ saltes. One of the Native chiefs, employed to superintend the collection of this production, accompanied me, and pointed out the similarity of Karang bollong, to the caverns: in which the Bird's-Nests are constructed; this I afterwards had an opportunity of determining by personal observation. To the projecting fragments of the Pudding stone the cords are atrached, which support the ladders and bridges employed in gathering the nests, and on this the collector

* Exp. Cat, No, 5 and 6. 
must rely: accidents however are very uncom. mon; and although the rock is liable to decomposition, scarcely an instance is recollected ac this place of the separation of the stone to which the cord was fixed.

I collected explanatory specimens of this rock both at the river Chiching-goleng, and at the cavern Karang-bollong, and the peculiarities of each will be pointed out in the explanatory catalogue which is attached to this Essay In the ascent of this hill (the first ridge of the peninsula pointed out on the map) the base of Pudding. stone is coverd by a deep soil, consisting of a mixure of clay and mould of decomposed vegetables: on the summit I noticed, at a spot where a section of the hill had been exposed in forming the road, a decp stratum of stone which wasa precipitate or deposite from water.* The materials were the same with those that form the Poudingue just described, but they were differently arranged; they exhibited plainJy the appearance of having been suspended in water and afterwards united into various forms ; in this place the layer which was exposed had been subjected to a current during the period that the present arrangement took place; fragments of various forms were hurled together, and the surface was covered with a friable earthy crust, indicating a greater degree of decomposition than appeared on the fracture; and the presentarrangement must have taken place after the first deposition or the first agglutination of the minute particles. 
Of the fra ments composing this stratum some were nodular, consisting of various concentric layers; some were tebular; ochers seperated readily into parallelopipeds, trapezimus or pyramids: in many casses large irregular masses were agglutinated without any shape. A similar deposition from water is one of the most common consituent parts of many of the separate hills composing the grand central ranges: those observed on this route will be pointed out in their proper places, with reference to the explanatory specimens. The fracture was yellowish, and exhibited clay in which minute particles of quartz, schorl, \&c. were bedded.

In ascending the second longicudinal range of this peninsula, I observed a deep yellowish soil from which large framents of Basaltes projected; the hill is steep, and several hundred feet above the level of the Ocean. At the Southern extremity is one of the principal Caverns inbabited by the esculent swallow, denominated by the natives Guwo-Dahar. The descent to the shore almost perpendicular, is $7^{2}$ fathoms: the stones which were brought up to me consisted of rounded fiagment of Basaltes, ${ }^{*}$ arising from the decomposition of the Poudingues; these had been collected at the entrance of the cave. The fragments of Basaltes on the summit, in this place, were mostly large; the surface was in a state of decomposition, and covered with a yellow friable earth. Some of the smaller fragments were nodular, and consisted of concentric layers. According to the account of the persons employed in collecting the nests, the Cavern extends with

* Exp. Car. No. 2. 
various windings about 200 fathoms into the body of the hill; tha breadth is not considerable, the perpendicular depth is about 10 farhomsand the sides are completely steep. It consists exclusively of the Putding-stone above described, to which the swallows atrach their nests. Above this Cavern several considerably elevated points project from the numerous ridges forming this peninsula, of which an extensive view is here afforded: their particular distribution is very irregular, and although the general direction of the assemblage is from North to Souch, many of the intermediate ridges stretch across the vallies from East to West. Karang-Kuda of the natives, which rises a little South-West of the village of Karang bollong, is here the most conspicuous point. It is composed of calcareous. *rock, containing various admixtures, and highly diversified in the composition: the foreign parts appear to be chiefly siliceons, and according to the account of the inhabitants, render it unfit for the preparation of lime for domestic purposes. The fracture of some exhibits small shells, others are of a coralline constitution, the nitrous a cid causes on all a strong effervescence. At the point where the eminence of Karang-Kuda is united to the ridge containing the Cavern above mentioned, an extensive groupe or assemblage of siliceous rocks is found, consisting principally of Hornstone, containing Hyalice and Agate, and often passing into Hornstone, $t$ Porphyry and Flint. The external surface, projecting beyond the earth, is often discolored,

* Exp. Cat. No. 3.

+ Exp. Cat. No. 4. 
appearing to be in a state of incipient decomposition. Some of the fragments partake of the nature of Hornblende, and these are also greatly diversified. This extensive groupe is in conjunction with the calcareous portion of the hill, the separate rocks penetrate deep into the earth; their relative position, in regard to the general Basis of this ridge, the Poudingue above described, I was not able to ascertain; but I afterwards fonnd the same minerals in other parts of these hills, and the extistence of extensive beds of siliceous stones, of almost every kind, in the grand central range and in the separate ridges deviating to the South, of which separate fragments are often carried down by the rivers, has been pointed out in the first section of the $\mathrm{Mi}$ neralogical Essay.

The principal Cavern in the whole peninsula of Karang-bollong, is sicuated about one mile West of Guwo-dahar, in contacr with the Ocean; from its size it is denominated Guwogedé, or the large Cavern: its height and transverse diameter are much greater than those of the Cavern abovementioned, but it does not extend so far into the hills. The perpendicular descent externally, from the eminence above the entrance at the ocean, is about 40 fathoms: its sides are also composed of rocks of Poudingue : several less considerable Caverns are found in the steep declivities towards the westward. Here I carefully noticed the termination of several ridges at the Ocean; they are perpendicular, or have a sudden inclination and the fragments of Basaltes, Sand, Lava and other volcanic materials are almose uniformly disposed in strata, the arrangement of which is more or less 
perceptible. Westwart of the large Cavern a consideroble Bay exists in this part of the peninsula, called the bay of Passir; and the range is interrupeed, in the north of the bay, by a sandy plain through which several villages are dispersed. From here 1 crossed the successive ridges towards the Western boundary, where likewise several extensive Caverns are situated on the Southern Decan, the chief of which are those of Nagassari and Fingkla.

The constitution of all the successive ridges is similar to that of the first and second above described: in several places, where vertical sections of the hills were exposed, I noticed, stones of aqueous deposition, either in the place where they appear to have been formed, or carried by a current to a distance; the former separated spontaneously often from immense masses, of which entirc ridges appear to be com. posed in the forms of cubes, thombs, parallelopipeds \&c. in the others fragments of varions forms were jumbled together, and the surface was uniformly covered with a friable earthy powder. The soil is in general deep, and blocks of Basaltes project from it, or are rolled together in the beds of the rivers. Approaching the village of Nagassari, deep strata of clay of a reddish colour are exposed on the sides of the hills. Above the caye of Nagassari the hill is composed of calcareous rocks, distıibured in irregular groupes, or piled upon each other in masses, rising many feet almost perpendicular. The sides are steep and regular, or rounded, cellular and excavated. The composition is*

* Exp, Cat No 8. 


\section{Essay, \&̈c.}

more uniform than the Limestone of Karangkuda, and the fracture exhibits numerous shells of various sizes; in some parts it is chrystalized and sparry : from this eminence the descent is on the whole gradual towards the Cavern of $\mathrm{Na}$ gassari : near the Ocean I found a vertical precipice of about 30 feet, to the rocks disposed near the entrance of the Cavern; this I descended on a common ladder of bambu. Here, on an extensive tract parallel to the ocean, immense rocks are scattered in every direction, resembling those of Karang-bollong: the entrance of the Cavern was discinctly observed about 20 feet lower, but at this time was inaccessible on account of the tempestuousness of the ocean, the surf beating against the rocks with great force: it was a simple fissure of about io feet perpendicular extent, gradually widening downwards.

A most extensive regularly perpendicular section of the hill was here exposed completely naked. The macerials disposed in strata having a very gentle inclination, were similar to those composing the vault at Karang-bollong; $\mathrm{Ba}^{*}$ saltes, lava and sand, forming an aggregate rock of the nature of Poudingue; nuclei of white sand, schorl, and minute chrystals of quartz were sometimes discovered on the fracture. A considerable diversity existed in the form and colour of the Basaltic fragments, but they all exhibited the marks of having been carried by a current and of attricion. Many of the specimens here consisted of minute particles, greatly resembling the Basaltic Tufa, which I frequently found on

* Exp. Cat. No. 9. 
the summits of the principal volcanoes, and of which the sides of the criters are chiefly composed.

The cave of Jingkla is situated near the South-wesc extremity of this Peninsula, in a ridge which is comparatively low, but terminates precipitously at the ocean and like the others appearing from above like irregular vaults penetrating the si es of the hill; these lead to a cavern less considerable than the others. In mauy other places which are here in view, the sides of the descending-ridges are excavated to a considerable depth, where they are in contact with the Ucean. Near the shore I found detached *fragments of calcareous spar and of $\mathrm{H}$ rnstone mixed with the disintegrated parts of the pousdingues. Descending the most western ridge of this Peninsula, I passed an extensive tract covered with rocis of limestone; they are highly irregular on the surface, and deeply furrowed or excavated; in many parts large rugged rocks impede the road, and occupy a conside rable range at the foot of the hill in contace with the Ocean. In my return from the west $\mathrm{rn}$ declivities of this ridge I took a different route, and observed at intervals piles of limestone, poudingues encire or in a state of disintegrtion, fixed and rolled basalric rocks, particularly in the basins of the tivers, and excensive beds of stones deposited from water.

The further remarks on the ridges which compose the Peninsula of Karang-bollong I shalt suspend, till the other hills which have a similar consticution in the western portion of the lstand,

- Exp. Cat, No, 12 and $x_{3}$. 


\section{Essay, \&e.}

have been described, and till the separate objects "of Lichology have been illustrated by the explanatory Catalogue: alchough the materials composing the grand central ridges and their branches are similar, it will be proper to follow them in the order of my route, and to point out the peculiarities which were observed. Atter leaving Karang-bollong, I proceeded closely along the eastern toot of the peninsula; at the village Adipollo the natives produced the stone which is employed in burning lime: it is a Stalactites of a loose cellular texture, formed in the numerous vallies of these ridges from the general mass of limestone, containing foreign admixtures: the latter, when exposed to a strong degree of heat, according to the account of the inhabitants, crumbles to pieces and affords a grit y mass, which cannot be employed for any of the purposes of lime.

In many parts of this route I noticed steep piles of calcar ous rocks, and irregular masses were distributed along the foot of the hills; the surface was very rugged. Rounded fragments occasionally projected from a deep soil, and in one place $\mathbf{i}$ found hornstone similar to that of Karang Kuda. Great portion of this tract is inundated during the rainy season; and even in the middle of the dry season many spot;, were marshy. The small trace of Ranka is situated towards the northern extremity of the ranges of Karang-bollong, and forms part of the extensive plain of Baggalen; in the north, the rising is scarcely perceptible; proceeding westward to the village of Selondokko, I passed the projec.

* Exp. Cat. No, 10 and $\mu$. 
tions of the numerous central ranges, and entered on an uneven tract; the ascent continues, with occasionally intervening vallies, to Chelenan the highest point on the large road to the capital of Banyu-mas; several rivulets intersect the road, in the beds of which are rounded masses of $\mathrm{Ba}$ saltes and Lava. The soil is deep, and on the whole fruitful. I found the various ranges which I afterwards crossed from the capital to the southern foot of Kali-weddi, on the route towards Talachap, of the same constitution. Upon the whole, great uniformicy is observed in the cencral and transverse ranges of this part of the Island. On all the soil is deep; and extensive masses of stone, formed by a deposition from water, with fragments of Basaltes rounded by attricion, are observed in most of them.

The lower tract of Ay?, which is bounded in the north by the projections of the ranges just described, and along the course of the southern shore by several ridges of low sand hills, is subject, during several months of the year, to the same inundation which takes place in the province of Baggalen eastward of the peninsula of Karang-bollong; but the greatest part of Aya is still in a state of nature, and its swamps are covered with impenetrable clusters of thornybambu (Pring-ori) various species of Erithrinaa, Mimosa, Ficus, Vitex, Eugeria, and other forest-trees, which from their distant situation are rarely applicable to any use.

From the southern declivities of the hills of Kali-weddi to the principal setrlement of Aya (Adipollo, Adirijo, \&c.) the road frequently meets the curves at the eastern banks of the large river of Serayu, the course of which is 
now very slow; in the westward a range is perceived, which runs off, iw a South-west direction, towards the Bay of Talachap. After crossing the river near its discharge, I proceeded nearly westward through a tract which is low and marshy: several bays and inlets introduce the water of the ocean, and it is covered abundantly with the common marine plants, viz: Rizophorae, Nipa, Hernandia, Tacca, \&̌c.

This tract extends in the same direction to the district of Cheribon: several branches of the grand central ranges run here towards the shore, nearly from North to South, directing the course of the Rivers of Juruk-legg', Chibrum, \&c. as they arrive in the lower alluvial districts they send off many transverse branches, which serve as canals to introduce the sea water through this whole tract, and give that disposition to the soil which is favourable to the production of the marine plants above mentioned.

The Island called by the natives Nuso-Brambang, extending from about one mile eastward of Talachap to the discharge of the river Chipakkat, is separated only by a narrow strait from the low tract of the opposite Island. This strait communicates in the west with an extensive Bay denominated Segoro-Anakan, and affords a discharge to the water accumulated by the Rivers of Juruk-leggi, Chi-brum, \&c.

Nuso-Brambang rises in this part almost precipitously from the Ocean: its constitution is of a mixed nature, bearing great resemblance to the bills which compose the central ranges I examined it in contact with the Ocean from the deserted village of Banjar, towards the eastern extremity; the points are mentioned on 
the Map, and on most I collected explanatory specimens (See the Map.)

Ac Banjar I noticed in the pebbles on the shore the following peculiarities:

Firstly - small fragments of very dense Basaltes, of a blueish color, resembling touchstone:

* Secondly-pebbles, the basis of which was Horublende, marked with numerous white lines, variously crossing each ocher, consiscing of deJicate lamina of Feldspar, the lustre of which was lost by attrition; in some fragments, how. ever, the lamina were extensive and entire, and these, sliperficially viewed, resembled granite:

$t$ Thirdly $\rightarrow$ a spccies of Sandstone which is pecnliar to chis part of the Island: the color is greenish, the grain very fine, and, in most of the fragments, a determinate form, consisting of four unequal sides, resembling exteriorly the common Basalces of this nei hbourhood, could be observed. Many fragments are cuboid, others rhomboid, \&c. I am led to suppose that extensive beds of this stone enter into the composition of the hills in a western direction from hence: in the eastern ranges I have hither to not observed it.

Fourthly-rounded fragments of Agate, Jasper, Hornstone, Porphyry and other siliceous: stones.

In ascending the hill in this part, which rises nearly precipitously a few hundred yards from the shore, $\mathbf{I}$ found again numerous fragments of the greenish stone just mentioned: in the rivulets

- Exp. Cat. No. 20.

t Exp. Cat, No. i7. 


\section{Essey, \&6.}

were detached basaltic fragments and rounded Poudingues of a close texture, consisting chiefly of Hornblende, in which we re bedded nodules of Feldspar and Quartz: the basis of the hill it." self, in this part, is a congeries of B saltes, which are occasionally observed on the Surface; this is covered with a decp black mould in which vegetation is very prolific. No great progress appears at any period to have been made in culcure; since this neighbourhood has beell disturbed by pirates, an entire desertion of the population has taken place, and the fruit trees remaining on the spots of the former villages and setulements, grow up promiscuously among the other trees of the forest. From Banjar I followed the shore to the principal points situated in the East: at Karang pachi (see the map) is a steep pile of calc reous rocks which ext nds, in different strate, a considerable distance along the shore: the surface is veryt irregular, and marked with deep cylindrical excavations; the fracture is by no means uniform, and it appenrs to contain a considerable admixture of minute crystals of quartz. At Ujungagung, which follows (a few hundred yards) further tastward a different appearance is exbibited. A very extensive Groupe of Volcanic rocks, occupies a considerable extent of the coast declining gradually to the Ocean and then stretching to the Eastwatd; in the South it rises \$ precipitously to the range which here composes the Island: it is a genuine lave, exhibiting the

* Exp. Cat No. Ig.

+ Exp Cat No. 2 .

S Exp, Cat. No. 18, 
character of this stone on the surface as well as in the fracture; but it differs from the others hicherto observed on the present route, in evidencly remaining on the spot where it was formed, being, on the whole, connected to one mass, not rounded on the surface, or exhibiting blunt angles, as those referred to in the preceding description, both such as were found in the beds of rivers, or dispersed among Basaltic rocks through the hills It appears, in my opinion, to come near to that species of $I_{a v a}$ which is distinguished very properly by Sir G. Mackenzie (sec Travels in Iceland) by the name of $\mathrm{Ca}$. yernous lava: I soon met it again in investigating the Southern coast, and it afterwards occurred, both in exposed situations, where it is acted on by the Ocean and in the midst of the cencral ranges.

It has appeared of importance to point out those minerals which remain in their original sicuation, and define the extent of the volcanic chasm in the bowels of the earch, as in most parts of the Island, although consisting almost exclusively of volcanic materials, these have been removed from the place where they were formed, and have been arranged in strata, often probably, at a great distance from the spot where they were acted upon the subterraneous cause. The constitution of the entire series of the irregular central ranges, is a prouf of this, and after this mineralogical sketch of the route, I shall endeavour to point out (with reference to the map) these points which remain in their original state, and those which have been arranged in strata. 
The external surface of this lava is rugged and cellular, the excavations are deep, and often confined by a narrow corresponding margin; ic has a particular disposition to burst into irregular, rhomboidal, oblong or cubical masses, some of which are very large: the fracture of separate particles is observed to be compact or finely vesicular, and contains much Feldspar and occasionally Zeolites. The whole groupe must be reckoned to the class of submarine lavas.

The appearance they exhibir to view is very striking; an extensive field in contact with the Ocean is here covered by rugged lava, and although the groupe is highly irregular, the disposicion to separate into rhombs and cubes is discinctly observed in the larger masses, which in alternate projections concribute to form a very irregular scene.

From Ujung-agung towards the furthest North-East point, I noticed, in contact with the Ocean, only calcareous rocks, excepting the pebbles on the strand, which were similar to those * of Banjar: ai Brambang the piles are very tprecipitous and the strata inclining: towards Karang-bollong near the point mentioned) the surface of the rocks is very unequal, cellular, and excavated with cylindrical furrows. I refer for their particular description to the explanatory Catalogue, see No. 17 to 24 .

From the river Serayu in a direction Eastward to the foot of the hill Badagangan, the tract is level, and at the present period (in contact

* Exp. Cat. No. 22.

† Exp. Cat. No. 23 . 
with the Ocean) in a state of cultivation: the soil is a mixture of clay and sand, and produces annually a plentiful crop of rice: Cacoa-nuc trees are very abundant. The river Adirojo flows along the Western foot of the hill mentioned; at its banks are exposed in many points, ptles of Sandstone of a texture more or less compact, and often of a stratified disposition, resembling the stone called padas in many parts * of the Island, and belon ing to the class of volcanic Tufa: on the Eastern banks of the river it is in conjunction with the rock of which the hill Bedagangan is composed: this has the same direction as the ranges of Karang-bollong, extending through the Southern parts of the plain of Aya, directly North and South, withouc any connection with the central ranges; its base in the parts I examined, is composed of cavernous lava, of submarine origin, and of constitution very similar to that found at the point Ujung-agung on Nuso-brambang. In con $t$ tact with this I noticed Pudding-stone of the same kind as that of Karantr-bollong. This hill terminates precipitously at the ocean, and contains here a fissure which is inhabited by the Hirundo esculenta. Near the discharge of the river Adirojo a large tract consists again of cavernous lava, compact in its fracture, bus highly rugged and irregular in the external appearance. Here extensive groupes project at low water, presenting rocks of a dark color, cellular, and excavated in great variety of form \$

- Exp. Cat. No. 25.

f Exp. Cat. No. 26.

5 Exp. Cat. No. 27. 


\section{Essay, \&ic.}

The fracture resembles that of many of our Basaltes, but contains a greater admix ure of Schorl. Some parts, in which Schorl equally abounds, are made up of a white fine-grained sand. Feldspar is comparatively rare. Eastward of this hill to the village of Jittis above mentioned, the tract near the Ocean is but sparingly cultivated; towards the North the whole is an inaccessible marsh, bounded by the central ranges; near the North East exremity of this, the village $P_{\text {ing-tuttul is situated, which has }}$ been mentioned in the Geographical description.

After the examination of the Southern portion of the province of Banyumas, my attention was directed to those districts which are situated North and North-West from the capital: these occupy a considerable part of the declivities of the mountain of Tagal, one of the principal links in the volcanic series of this Island. Having crossed the river of Serayu, and passed several eminences which are covered with a deep soil, I entered on a tract nearly level, having only a gradual ascent in the North; it is compos. ed of the districts of Passir and Probolingo, being bounded in the East by Banjar, and in the North and West by several of the Honorable Company's districts belonging to the residencies of Tagal and Cheribon

Near Suko-rojo, the situation of which is marked on the map, a tract commences which is covered almost entirely by 'Tulf or Tufa, either united or in a state of disintegration, stretching about 12 miles to the Westward, till it meets the ridges extending from the declivitics of the mountain of Tagal towards the Southern shore."

* Exp. Cat. No. 28. 
This Tufa is exposed in extensive stratified masses at the banks of the rivers and rivulets, which are filled with the separated fragments, mostly rounded by attrition: its texture is very loose, and the component parts, of minute fragments of basaltes, pumice, gravel and sand are distributed over the whole territory, and have probably given rise to the name of Passir, signifying sand or gravel, for the whole district. The proportion of clayey parts which were mixed with the Tufa have also accumulated in extensive masses, and contribute probably to the productiveness on account of which the soil of these districts, in many places, is celebrated.

Besides the rivulets near the villages of $\mathrm{Ba}$ gor, Suko-rojo, Purwo kerto and Probolingo where it is very abundant, I noticed this Tufa, in a state of agglutination, in various other situations; it generally crumbles away on being taken up, but has also remained entire, covering large surfaces which resemble the more compact Pudding-stones of Karang-bollong, and resist the effect of the water flowing over them: but on the application of any force, as the stroke of a hammer, they instantly fall to pieces. The peculiarities in regard to other tufas of this Island, will be pointed out in the explanatory Catalogue.

In proceeding to the westward, the vicinity of a volcano in strongly indicated by the substances which have been carried down by the currents, in the rivers; the streams of Banjaran and Logowok in the rainy season are very considerable, and their basins in the dry season are filled * with fragments of lava, indicating apparently a

* Exp. Cak, No. 30. 


\section{Essay, छ̈a.}

* more recent origin than those which are found in the central ranges, in conjunction with the bills, formed by a deposition from water, and at a greater distance from either of the principal volcanic points which have lately been in action. It appears indeed probable that they were ejected by an eruption comparatively late, in as far as relates to the general arrangement of the strata of this Island: their character is different from those of Ujung - agung and Bedagangan above mentioned, which belong to the submarine lavas, and I shall soon point out the traces of a very extensive stream which flowed in a S. S. W. direction from the mountain. It has, however, appeared to me that the Tufa which principally composes this tract has a still more recent origin, and if many of the lavas must be considered to have been formed under the ocean, this tufa appears to be a mere mechanical agglutination of the substances of one of the later eruptions. Proceeding westwards from Purwo-korto I passed several of the projections from the central ranges, running out before the foot of the large mountain, and the indications of the Tufa were gradually lost. At Ajibarang the vicinity of an active volcano, already indicated by the detached fragments in the rivers of Banjaran and Lo-gowok, was more strongly exhibited: near the declivities of several of the ridges just mentioned, I traced, South of the chief village of this district, a stream of lava which appears to have flowed from the mountain in this direction: the vestiges of it covered an extensive tract in a de-

* Exp. Cat. No. 3r. 
clining situation, and extend to the rivers bounding it in the East and West: the lavas project in some parts in connected groupes, like rocks of granite from primitive mountains, or they are thrown together in detached fragments; the intervening spaces being covered with a deep vegetable mould: their surface is either smooth, like that of Basaltes, or cellular like scoriæ: * In the river Datar, which I followed several hundred yards through various windings and small cascades, I found an extensive chanuel of compact lava, consisting, in many places, of a vertical height of 30 feet.

Near its banks, an extensive fissure of one of $f$ the ridges disclosed a cavity about 30 feet deep, consisting likewise of compact lava, separating spontaneously into large, more or less determinate blocks, often with regular sides, the surface of which is cellular, and in many instances of a reddish colour; the mass composing this eminence must be considered of anterior date, being covered by a thin stratum of rolled Basaltes of various sizes, mixed with sand and gravel. The stream in contact with this on the descent above mentioned, and probably also that which composes the basin of the river Datar, exhibited the appearances observed in our volcanoes after recent eruptions; separate disjointed blocks promiscuously thrown together, with adjoining groupes, more or less regular, approaching the nature of Basaltes, are often exhibited, as has been mentioned in another place.

- Exp. Cat No. 33 .

† Exp. Cat. No. 32 . 
The color is black or inclining to red, the fractory compact or vesicular; in the former various foreign admixtures are perceptible, which will be pointed out in the separate description; in the latter the concavities are often numerous and close: these resemble the lavas rolled from our craters by the most recent eruptions, in a semifluid state, partaking of the nature of slags : many of those in which the fracture was compact could scarcely be distinguished from the common Basaltes of this Island.

At the river Kawung, which flows near the Western boundary of this tract of lava, in a situation about two miles North, inclining to the West, of the groupe above mentioned, I observed the most regular assemblage of prismatic stones hitherto noticed in any part of this Island; the fragments appeared to remain in the spot where they had been formed, the angles were still regular and sharp, and the extremity projected in -most cases towards the rivulet with very little inclination. The separate fragments were four sided, and the angles mostly regular; the whole groupe occupied a length of about 30 yards near the rivulet, and 5 or 6 fragments were piled almost perpendicularly on each other; in a few intances only, they presented the longest side. This assemblage was remarkable, as it exhibited the only prismatic stone (of the Trap family Basaltes) I had hitherto noriced in which the angles were not rounded by attrition or shewed the marks of having been carried by a current.

In the river Tiajum I found again, in a situation South-west of the village of Ajibarang, the indications of the extend of this tract of Lava: here the fiagments were mostly scparate 
but of immense size, and strewed promiscuously in the basin of the river; they appeared to form in this point, the western boundary of the tract, which, beyond the river, was met again by a hill descending from the grand central ranges in this direction.

The western banks of the river were confined by several ridges of moderate elevation; at the spot which I examined, a pile, of a somewhat pyramidal form, rose precipitously to the height of several hundred feet: the side near the river was completely naked, and exhibited its internal constitution. At the base a rugged mass projected, which at a distance resembled Lava, but on near examination was found to be an aggregate rock of a grey color, consisting of sand, ${ }^{*}$ calcareous spar, and clay in various proportions of admixcure: extensive groupes of spar appeared on the surface and on the fragments which were broken off: detached masses of a similar rock were afterwards found on the opposite side of the river, which were more compact, and in the fracture resembled amygdaloids ; $\dagger$ they consisted chiefly of nodules of clay, bedded in a sparry mass. Resting on the aggregate grey rock at the base, and composing the greatest part of this eminence, was an extensive assemblage consisting entirely of a deposition from water, of great variety of configuration and arrangement, but chicfly of lamina and nodules. The whole side of the hill which was exposed exhibiced this deposition in a nodular or tabular form, in groupes alternating with or mixed

\footnotetext{
* Exp. Cat. No. 34.

t Exp. Cat. No. 37.
} 
through each other without any determinate order: the separate fragments had rolled down, and were found at the banks of the river, and bold strata extended into it and formed part of its basin; the arrangement of the separate nodules was in concentric layers, but on being taken * up or removed from their original situation, they burst transversely and crumbled away in irregular concave lamina. The predominane color of the fracture was blueish-grey, externally most of the fragments were covered with a dirty yellowish ochreous crust: they slightly adhered to the tongue.

In attempting to ascend the hill, the various masses rolled under the foot and carried one back again; the top was covered wich long grass. Some yards North of the groupe of grey rocks, at the base, in contact with the river, a mass was deposited which approached $\dagger$ the nature of sandstone: the portions which composed it had a disposition to separate in a more determinate angled manner, forming cuboid or trapizoid fragments, not unlike the configuration of many of our basaltes: the fracture was bluish and compact, and they were covered with a yellowish crust. A simple sandstone was also occasionally found in contact with the other assemblages forming this hill, resembling the grey rock at the base, buc without any admixture of spar.

The district of Passir extends to that part of the foor of the mountain where the acclivity

* Exp. Cat. No. 35 .

† Exp. Cat. No. 36 . 
becomes more abrupt; here it is bounded in the North by the small trace of Kumucuk, beyond which, the South side of the mountain has not been examined: the territory also consists of * Tufa resembling that of Purwo-kerto, but from the natural inclination of the district, all the small and loose fragments have been washed down towards the southern valley. It is covered by a deep soil, accumulated chiefly from a very luxuriant vegetation during a long period. In some parts a lava is exposed in the rivulets resembling the more compact kinds of $\mathrm{Aji}-\dagger$ barang.

The constitution of Probolingo resembles that of Passir; towards the eastern boundary the quantity of sand and gravel on the surface is less abundant, but at the banks of the river Kelawing, near the chief village of this district, immense piles of Tufa are exposed, often to the depth of 30 feet, which, as well as that found near Suko-rojo, has compactness enough to be cut into tables or slabs, and employed in flooring the dwellings of the natives and for various similar purposes. In the pebbles of this river, carried down by the current, I also noticed the indication of extensive beds of siliceots stones in the central ranges: with the common rounded fragments of Lava, Basaltes and Sand-stone, were mixed Agates of various kinds, Prase, simple Hornstone, Hornstone-porphyry of grent variety of colour and fracture, and a species of $\$$ Sandstone of a verdigris-green colour, having

\footnotetext{
* Exp. Cac. No $4 \mathrm{r}$.

t Exd. Cat. No. 42 .

5 Exp. Cat. No, 2\%,
} 


\section{Essay, E2c.}

a disposition to a regular angular form, like the fragments of green sand stone found at NusoBrambang: in the fracture appear minute particles of varying shades of colour, consisting of * Horn-stone and orher siliceous stones.

Between the mountain of Tagal in the West, and the Sundoro and Sumbing in the Easr, the body of the Island is occupied by various ridges, the direction of which on the whole is from East to West. From the vicinity of the Sundoro they take a northern direction, and from the mountain of Tagal they incline to the southern shore. These ridges consist of several irregular chains of hills, the particular stretch and distribution of which cannot easily be ascertained with accuracy, as they are connected by numerous transverse links. From the intervening declivities and vallies many separate mounds of an oblong or conical form arise, which are almost uniformly rounded on the surface and covered with a deep soil.

Almost in the middle of the Island a very extensive valley exists, affording a basin to the large river of Serayu, receiving from the North and South numerous streams flowing to this central excavation, from which, in both directions, the ascent is gradual, but considerable. The highest points in the North are the mountain Prow, and in the South the Kuripan or Gunung Iju, two very conspicuous points, from which the territory continues uneven to the northern and southern shore, consisting of numerous vallies and irregular ridges. The valley which transmits the river Serayu was in

* Exp. Cat. No. 23. 
former times distinguished by the denomination of Lurung-tengu or the middle valley, a name which is sometimes applied to the whole province of Banyu-mas, and the adjoining districts in the centre of the Island: from the capital, the direction of the river is soon turned off towards the South, by the branches of the central ranges descending in this direction.

On leaving the capital of Banyu-mas, I first pursued the common road leading to the eastward, which in the lower parts of the valley runs nearly on a level with the Sernyu; I mee the curves of this river in various places: On this part, to Purwo-ro o, I observed on the projections from the central ranges which I crossed, extensive masses of a deposite from water, similar to that above described, Rasaltic rocks, with angles rounded by attrition, rising from a deep reddish soil, and in the beds of the rivers of Piosso, Deris and Sapi, fragments of Basaltes and Lava; some of the latter were very cellular, and resembled those of the acclivity of the mountain abovementioned. At Purwo-rejo I could take into one point of view the first range of central hills, rising to the North of the valley of the Serayu, at the distance of about 8 miles: these are mostly long extended eminences, similar in their appearance to those stretching from Rangka to Kali-weddi, and indicating, at a distance, the same constitution: disposed among the extended ranges were observed precipitous piles, rising in many cases almost perpendicular, the nature of which is in a great measure elucidated by the hill Lawet, to be mentioned in the sequel: the elevation of all these, in comparison with the large mountain of 


\section{Essay, छ̈c.}

Tagal, the Sundoro and the Sumbing, is not considerable: these their principal volcanic points could here be taken into view at once.

On the track from Purwo-rejo to Gomuro, the numerous terminations of the descending ridges alternate with leved districts: they are all covered with a deep reddish soil or with vegetable mould: on proceeding to the eastward, the declivities which form the valley of the Serayu come nearer to each other. Between Gomuru and Kutco-waringin, I crossed this river about a mile below the entrance of the river Merawu, which descends with a rapid stream, in order to examine the principal of the northern eminences of the central ranges. As this point an extensive stratum of Puddingstone is exposed at the banks, which is either compact, like that of Karang-bollong, or loose and friable, like the Tufa of Suko-rojo. Several of the separate fragments which I detached with some difficulty, resemble greatly the common Hornblende of Werner, although they must be classed with our Basaltes. This as well as the two specimens of aggregate rock * are decscribed in the explanatory Catalogue.

Of the rounded pebbles collected in the bed of the Serayu, the most remarkable were a compact Pudding-stone, apparently brought by the current from a distant situation, and a peculiar stone ( of the Floetz-trap formation of Werne) resembling Wacke, of an obscure bluersh grey color, traversed with white lines of various breadth from that of a hair to half an inch; Their direction is curved or undulating, and

*Exp. Cat. No. 45. 
rarely regular, in some instances however they cross each other at right angles. The number of these lines is various; in some fiagments a single streak was observed, in others the whole surface was variegated: they consisted chicfly of calcareous spar, as appeared by the application of an acid: the surface of all the fragments * was strongly rounded by attrition. The frag. tments of Basaltes found in the river, were of different constitution, and indicated a derivation from different original situations: in some, small crystals of schorl formed a chief component part, orhers consisted, in great part, of minute groupes of Feldspar.

From Banjar I pursued my route in a Northern direction: this village is situated on the stream Merawu, about 2 miles above its discharge into the Serayu. Several very considerable points of the central ranges fall in the route I had proposed; they will be enumerated in the order I met them; but for their relative situation I must refer to the map which accompanies this Essay. The first is the hill Pawinian, which lies nearly North of the village of Banjar. The road traverses the Eastern declivities: these are divided by several deep ravines which are covered with a fertile black mould; in the vallies rounded fragments of basaltes are accumulated.

Almost directly East of the highest point of this hill, the steen pile, called Gunung-Lawet by the natives, is situated, which by its precipitons elevation attracts considerable notice at a

- Exp. Cat. No. 43 .

t Exp. Cat. No. 44. 


\section{Essay, Ẽc.}

distance: as the road passes between the two hills, I had a good opportunity of examining it wich care. When observed a far off, it appears to consist of several massive rocks which rise almost perpendicular from an extensive base: the Southern side appears cragged and broken, the Norchern has a gradual inclination. The steepst parts are naked, the foot and severaspots on the declivicies are covered with shrubl and plants.

After a gradual ascent through a narrow pas sage or ravine, becween the two hills, which is strewed with the detached frogments compos* ing the Lawet, while the sides expose the same fragments closely arranged on each other, I reached the base of the Western pile. Here (in the Souch where I first examined it) it rises several hundred feet perpendicularly, being composed throughout of an assemblage of Basaltes. The form of the separate fragments is on the whole regular, consisting of prismatical masses, with defined angles: of considerable size. Some fragments had oblique angles, constituting rhomboids, pyramids, \&c. with these regular prismatic or rhomboidal fragments, alternated iu many places nodules of the same substance consisting of concentric layers.

The aggregate of the various masses on this side, consticuted a stupendous wall, the component particles of which, move or less regular in themselves, were irregularly piled on each other, the alternate portions projecting and retiring from a perpendicular line.

The largest fragments, like many other besaltes, are marked with horizontal lines, indicating a further disposition to separate in 2 
manner similar to the fingnients already detached: many of these are regularly tabular: The extent and boldness of this pile forms an interesting spectacle, of which it is difficult by description alone to give an adequate representation; it explains at the same time the constitution of the other perpendicular piles which are dispersed through the central ranges, and by their contrast with the rounded or extended ridges, attract the attention of the mineralogist. The Basaltes at the foot of this pile has a similar form, but the angles which project from the soil are blunt and rounded by attricion, shewing, as it were, the effect of substances which have been carried over them by a current.

On the fracture a grey or whitish color pre. dominates, in consequence of the abundance of particles of feldspar and quartz, whicb enter * into its composition; through these are dispersed numerous crystals of schorl, hornblende and some times Augit. These also appear on the surface, which more than other Basaltes of this Island, inclines to a white color. Observed at a distance, this hill may easily be mistaken for an assemblage of calcareous rock.

The northern side of the western pile constituting the Gunung Lawet is much more uniform; it rises nearly perpendicularly, wich very slight inclination, and no distinct separation into portions or fragments is perceptible: ic exhibits the appearance of a stupendous wall of whitish colour, variegated only by a few excavations, apparently of later date, and (by no means numerous) longitudinal lines.

* Exp. Cat. No, 46. 


\section{Essay, Esc.}

On the further route between the Gunung Lawet in the East, and the hill Pawinian in the West, I noticed numerous fragments accidentally detached from this pile: they were remarkable on account of the regularity of their form, which was mostly tabular, the angles were defined and still entire, bearing no marks of external attrition. Here I also found several other substances (of the same Floetz trap formation according to Werner), but apparently of a more recent deposition: the most interesting * were several varieties of Sand-stone, one of which consisted of small uniform Lamina, abour a line in thickness regularly imposed on each other, with defined sides and angles: in a second the fracture was uniform (like common Sand-stone) and the separate fragments appeared in rhomboidal and trapezoidal masses.

After passing the ravine between the mountains Pawinian and Lawer, a considerable prospect is afforded of the adjacent country it the North the hill Telogo-leli is the second point, in this part of the central ranges, deserving notice on account of its elevation; at the fooc of it the river Uren is observed winding in a deep stoney valley; numerous small hills, irregularly scatterred, are observed in this tract, rounded on the surface and covered with a deep soil. The road now took a western direction, following for several miles the northern declivities of the hill Pawinian, which here is chiefly formed of a deposition from water, in many places concealed by a deep earth or by a vegecable mould, in

Exp. Cat. No. 47 . 
others it is bare and appears on the surface; itg conscitution agrees with that above described, composing a steep hill Souch of Ajibarang on the banks of the river Tiajum, bur it is disposed in layers which have a gentle inclination and apparently penecrate far into the body of the hill. Externally of these layers the various substances which form the base of the surround. ing tract, are irregularly mixed together: among these were likewise fragments of volcanic Tufa, which I soon met in extensive piles. Some of this was coloured by i on (vide Sp. No. 49). The most rem rkable rocky substances entering into the composition of this part of the Pawinian *hill were; I: a sand-stone separating into rhomboidal and trapezoi tal fragments, with angles mostly defined; some portions are lamellar and penetrated by and ochreuus efflorescence; 2 , a massive precipitation in which no regular form could be observed, consisting of clay, and separating like coagula of that earth, when dry, into various amorphous particles. The colour was grey of a blackish hue, and it adhered slightly to the tonque.

At the Western extremity of the mount $\mathrm{Pa}$ winian the road again takes a Northern direc. tion towards the eminence of Paggar-pella: the surface is uneven, and occasionally exposes the continuation of the strata which abound in the whole tract. The principal village of this neighbourhood, is also distinguished by the mame of Pagger-pella and situtited near the top. of this eminence; the ascent, from the South, is strewed with numerous tabular fragments of $\mathrm{Ba}$ -

* Exp. Cat. No. 48, 


\section{Essay, $\mathcal{E}^{2} c$.}

saltes; in the deseent, in the opposite direction, the road was cuc through a deep stratum of this * stone in a state of decomposition. I is hardness and adhesion was so completely destroyed, that it was as easily divided by a cutcing i stiument as a'mass of clay or earth : if taken up by the hand it crumbled to pieces. The fracure resembled that of the Basaltes composing the pile of Gunung-Lawek : the white colour predominated, the lustre of the feldspar was lost, and the other component parts were eathy and ochreous: in some particles the angular form was still discernible in others the whole was united into one uniform mass. This decomposed Basalces was afterwards found abundantly in the central ranges, where it constitutes one of the pricipal bases of our hills : the causes which have effected or influenced this decomposition. have heen peculiarly operative in certain tracts and situations Many of the fragments above this decomposed stratum were very compact, and resembled the Wernerian Greenstone, consisting of minute irregular particles of feldspar and tgreenish hornblende, incimately mixed: among these I selected specimens of very determinate sides and angles : in the village of Paggerpella several very large rocks of this substance projected from the soil.

On the descent al ovementioned a third point of considerable elevation is first observed in coming from the Souch, the hill Roggo-jambant* gan. exceeding in extent of base, and probably in height both the Pawinian and Telogo-leli. At

* Exp. Cat. No, 50.

t Exp. Cat. No. $5^{\text {t. }}$ 
the Northern declivities is a nearly extinct volcanic crater, forming one of a series in this part of the Island which will be mentioned in the sequel. At the foot of the hill of Pagger-pella I crossed the river Urang: the fixed rocks near the banks are Pudding-stone and Basaltes; the pebbles in the basin are very much diversified; I selected the following, all evidently derived from a distant situation in the central ranges: viz:

1 . * Lava of eneirely vesicular consticution.

2. +Lava of the kind of sub marine lava above mentioned, conraining calcareous spar in narrow layers or irregular masses.

3. H Compact clay in tabular fragments, the angles of which are rounded by attrition.

4. † Compace udding-stone (or Amygdaloid) consisting of minute fragments of Basaltes bedded in a clayey cement. layers.

5. $\$$ Sandstone in curved and recti-linear

6. $\int \mathbb{S}$ Petrified wo'sd with stony concretions.

The territory between the three principal hills of this part of the central ranges, the Pawinian, Telogo-leli and Roggo-jambangan, is covered by numerous inequalities irregularly dispersed, of which several deserve the name of hills: on the ascent of the ridge called Sari I met again stones of watery deposition. The village of Karang-kobar, the chief of the district of the

\footnotetext{
* Exp. Cat. No. 52 .

f Exp. Cat. No. 52b.

$t+$ Exp. Cat. No 53.

++ Exp. Cat. No. 54.

\$S Exp. Cat. No 55.

Exp. Cat, No. 536 .
} 


\section{Essay, Eेc.}

same name, in a direction nearly E. N. E. of Pagger pella, is situated in a concavity surrounded by low mounds with obtuse summits, by which the prospect is much confined. They are all covered by a deep reddish soil. Proceeding in a North East course 1 found agaiu an extensive sction of a hill, composed entirely of the same substances which form the principal bulk of the stratified points at Ajibarang and the Pawisian, being a pile of clay and Sandstone, in various modifications, and separating spontaneously into prismatical, rhomboidal and trapezoidal fragments, between which nodules consisting of concentric layers, formed of the same materials, and covered with an earthy * efflorescence, were thrust in. Traversing these hills in the direction above mentioned, after leaving the environs of Karang-kobar, I noticed in several spors, extensive beds and masses of Basaltes in a state of entire decomposition, resembling those of Paggar-pella; and in the further progress, the basaltic rocks, which projeted from a deep yellow soil, were much rounded at the angles by attrition.

Among the hills on the route to Kali-lunyar and in the environs of that village, are several elevated points projecting from the neighbouring unequal terrirory (which are marked on the map) namely, the hills Krangeang. Gaja and Lumbung, besides others of less note. The constitution of these is elucidated by the ap, pearances I noticed in a valley near this village: here the depositions from water were very abundant, they extended almost perpendicularly

* Exp. Cat. No. 56 . 
or with very sudden inclination into the body of the hills The substance of which they wore composed was almost pure sand of a coarse * grain, or fire sand and clay in nearly equal proportions; the latcer was of en reddish color. The arrangement of these substances was either lamellar or nodular in concentric layers : these occurred alternating with each other; but from the appearance of their relative arrangemsnt they hid remained at rest from the period of their first precipitacion.

From the valley of the river Serayu to the ranges in the vicinity of Batur, the ascent is gradual but constant, and only interrupred by occasional ravines and vallies: this is strongly indicated by the vegetable productious; I shall only adduce one instance; at Karang-kobar although the Cacio nut tree bears fruic, is productiveness is comparatively very scanty; at Kali-lunyar the tree vegetates without producing fruit; beyond this village to Batur no Cacao-nut trees are found, as they cannot sup. port the climate of this elevated situation. The district between Nusupan and Batur affords a coutinuation of the appearances already described on this route: st nes of watery dep sition are often expased by the sections of the hills; $t$ the soil is deep and of a reddish color, the frag. ments of Basaltes which are occasionally strew. ed on the surface are strongly rounded at the $\$$ gngles, and extensive masses of this substance

* Exp. Cat. No, 57 .

t Exp. Cat. No. 59.

SExp. Cat, No. 58 . 
occur in a state of decomposition, forming in * some instances the base of entire ridges.

Batur is situated on the South-west declivities of the highest series, extending from the western foot of the mount Roggo-jambangan to the eastern excremity of the mountain Prow: the most interesting points of these ridges, in a direction from west to enst, are the hills Butak, Piarangan, Pakerman, Nagassari, Koppok, Wismo, which deviates towards the south, and Diyeng and Telogo-Jebong, deviating towards the north. The assemblage of the Koppo, Biyeng and Tologo-jebong, with several other points, is denominated Gunung-Prow, from the appearance it exhibits at a distance: it projects considerably beyond the other points of this ridge.

According to a probable estimate, the elevarion of Batur is equal to that of Selo on the Mirbabu: this estimate is founded on the comparison of the vegetables growing in both situations, and on the temperature indicated by the thermometer: I found it on the 24 th of October at Sun-rise at 5.3 of Fahrenheic's scale. The terricory in the south is open, and exhibits an irregular succession of ridges, gradually descending to the valley of the Serayu, but without any uniform direction. Several long-extended ridges, with occasional bluff points, irregularly scattered, project more than others, they all indicate externally a formation and composition similar to these hitherto traced from Banjar to Batur. In the north of this village, the nearest point, the hill Ptarangan rises, about 
half a mile distant, with a precipitous elevation. I ascended it, and estimate its elevation at least 1000 feet above the surrounding level; is is covered with a deep soil and high y luxuriane vegetation: Basaltic stones in extensive layers ar accasionally observed on the ascent projecting from a deep soil: their surface is burst and covered with an earthy ochreous incrustation.* Several detached fragmonts have a reddish color, and indicate the existence of beds of decomposed Basaltes near the foot of this hill.

The hill Butak, (which name, according to the application of the nutives, includes the assemblage of all the ridges situated immediately North and North West of Batur) is connected, in the North-West, to the declivities of the hill Pcarangan, and in the east they pass into the $\mathrm{Pa}$ kerman. This mountain is well known on account of the volcanic apertures which exist in its declivities: one of these is denominated $\mathrm{Gu}$ wo-upas or the Poison-cave, by the natives, in consequence of the deleterious effect of the air it discharges on the animals that approach it, the orher, the crater or Kawa of the natives, lies at the Western foot of the mountain, and explodes, at intervals of a few seconds, considerable volumes of smoke. The diameter of this opening is about 30 feet and its depth is considerable; near it is a smaller one about two yards wide. The natives have a superstitious aversion to appronch these apertures, and I yielded to their sollicitations, at the sacrifice of the curinsicy to examine their appearance : this was of lessimportance, as frequenc opportunities. accur of observing similar outlets.

* Exp. Cat. No. 6?. 


\section{Essay, Ecc.}

This neighbourhood was convulsed by the operation of a subterrancous combustion about the year 1786: after atr earthquake which continued, at intervals, for the period of four months, an eruption forced its way not only through the existing volcanic apertures, above mentioned, but thruugh the neighbouring territery to the extent of two miles in diameter. Various rents were formed which emitted a sulphureous vapour, separate tracts sunk away and were swallowed up by the earth; in one of these the waters of the rivulet Dolog entered and afterwards followed a subterraneous course. The sulphureous vapours were observed in the atmosphere four successive days. The village of Jampang, at the confines of this convulsed tract, was likewise buried in the ground, and the inhabitants who trad not timely left their dwellings perished: several persons were killed by the materials ejected from various openings. The aggregate number of persons who lost their lives on this occasion, most of whom were females, is estimated at 38 . This information was communicated to me on the spot, by two of the principal Demangs (or chiefs of villages) of the Karang-kobar district, both natives of respectabilicy; one of whom personally witnessed the event. At the present period the effects are nearly obliterated, the sides of the excavations being covered by a profuse vegeration. I noticed the remaining concavities, and visited that in which the revulet Dolog sinks away. The water first accumulates in the remaining basin, which is about 30 feet broad, at the foot of a steep eminence, surrounded by large rocks of 
Basaltes, and then almost insensiby filtrates into the earth. During the rainy senson, when the warer is increased by a strung afflux from the hills, a portion sill follows the original bed of the rivulet. On the site of the village Jampang I observed a molerate excavation: it is deserted, and-the remaining inhabitants have fixed themsclves at Kassirdn a village near the roa.i leading from Batur towards Kadu.

Near the southern dicliviries of the mountain Pakerman, the mountain Nagassari is situated, str tching considerably to the South, and still further, in this derection, inclining gradually to the ensiward, the mountain Wismz. The extent and elevation of the latter is more considera'ble than that of the Pakerman, Nagassari and the others of this range, all united at the base, and forming an assemblage, posscssing separately almost the same degree of elevation: Their external appearance is likewise similar, they constitute somewhat extended ridges and the sides are excavated by deep ravines.

In various excursions throngh the declivities of the hills of Pcarangen, Pakerman and $\mathrm{Na}$ gassari, I selected explanatory mincralogical specimens; the most interesting were:

1. Compace lava of a blaish color.

* 2. Porous or cellular lava (emittiug when struck the sound of bricks) of a red colour : of this several varieties are found in different situation; on the whole the color abounds in this district, both in the lavas and in the soil.

* Exp, Cat, No, 62, 63, 64, 65 and 66 . 

angles.

3. Compact Basaltes with determinate

4. Several varicties of Basaltes in a state of decomposition, of which cxtensive beds are found in the vicinity.

In the route eastward from Batur, I first followed the Southern foot of the Paikerman and Nagassari; the road subsequently winds to the North between this hill and the mount Wismo and gradually ascends. On this track I passed the rivulet $F u t$ and the remmant of the rivalet Dolog, and observed, very distinctly, the explosions of the Crater of the Pakerman appearing regularly after an interval of a few seconds.

Having passed the Eastern declivities of the hill Nagassari, the road approaches the hill Koppok, which conceals the Eustern points of this range. In proportion to the elevation of the district and the vicinity of the summits of the hills, the ravines become deeper and the ascent more abrupt. The river Tulis which after receiving the rivulets of Pati and Dolog, pursues a Southern course, and forms one of the principal branches of the Serayu, winds through a very deép valley on the sides of which bastltic rocks are exposed: these are observed in large masses, forming extensive piles on the acclivities further eastward; their angles are all rounded by attricion. The elevation is now apparently about 1000 feet above the level of Batur, in as for as it is indicated by the vegetable productions : very few of those growing in the lower parts of the valley of the Serayu are now met with, but Casuarina Chomoro is here the

* Exp Cat. No, 6r. 
most common tree: the trunk is abundantiy covered with various kinds of moss, resembling that of the Northern countries of Europe: many species of Epideadrum, of Lycopodium, \&c. commonly found in colder climates, are suspend. ed from the branches. The number of rare Ferns is also considerable.

* The territory near the summit of this connected ridge, is covered with a reddish soil, mixed, near the surface, with black vegetable mould. The village of Konang is situated in a slight concavity, surrounded on all sides by several narrow ridges, descending from the mount Diyeng, and inclining towards the mount Wismo ; the principal of these, in the South, is the Wagertipis. In the North of this village, on the descent of the mount Diyeng, another volcanic opening exist, which, like that of the Pakerman, emits smoke at intervals. On this elevated tract, covered with a highly fertile soil, vegetation is very luxuriant; several plants are spontaneously poduced, which in general, are considered as the exclusive inhabitants of colder climates.

On the descent of the hill Telogo-jebong (the denomination which is here univormly. given to the Southern declivities of the mountain Prow) I noticed lava, basaltes and pudding. stones alternating with each other, and recurring at intervals without any determinate disposition. Both the lava and basalres have been em. ployed in the construction of an artificial stair, which extends through the greatest part of the

Exp. Cat, No. 68. 
descent of this mountain, and which consticutes one of the most stupendous vestiges of the ancient inhabitans of this Istand; in a fragment of one of the slabs of which the stair is constructed, among the explanatory specimens annexed to this Essay, the frocture exhibits various foraminula filled with a white siliceous stalactitical substance, the rest is composed of quartz and hornblende, through which mica is *sparingly dispersed. This mountain, as well as the Diyeng, contains several extinct volcanic apertures which at the present period are filled with water, and constitute, ,Telogos" or lakes according to the denomination of the natives. From the Telogo-jebung the whole mountain has been named; at the foot I observed the Telogo-menjer near a village of the same name. The descent of the mountain to the village Kayu-Rangkang, near the lakes last mentioned, is very sudden, and the perpendicular elevation from here to the summit is at least 1500 feet.

From the village Kayu-Rangkang to the river Serayu, which I crossed near the Chinese farm of Jawar, the descenc is gradual, and only interrupted by the ravines descending from the neighbouring mountains, and meeting each other from various directions. The Serayu flows with a rapid current from north to south, arising from the hill Jajar, near the Fastern declivities of the moutain Prow: its basin is strewed with large rocks of Basalres.

On the route from Kayu-Rangkang towards the south, I observed on the sections of the hills that were accidentally exposed, Tufa of various

- Exp. Cat. №. $7 \%$ 
constitution: it was often arranged in strats and resembled a coarse sandstone, but its adhesion was generally so slight, that it cruinbled to pieces if removed from irs original situation; in some instances, however, it was compact.

The village of Kali-Bebber is situated about eight miles south of Kayu-Rangkang, in a trace which gradually declines towards the central valley, thedirection of which, in this part of the Island, is nearly from east to west. The river Serayu (not-far from its source) flows towards it from the north; the river Begalu from the east; besides these many smaller streanı from the neighbouring mountains direcr their course rowards it, and contribute to one of the principal vivers of the Island, which has already frepuently been mentioned in the preceding Essay.

Not far from Kali-Bebber the territory sensibly rises in the north-east towards the mountain Sundoro, one of the principal points of the great volcanic series, which indicates at present the continuance of the subterraneous combustion, by occasional discharges of smoke and flame, and the appearrances in the vicinity afford the strongest marks of former eruptions of a more formidable kind. Besides rocks of very considerable bulk and extent projecting from the soil, the surrounding territory is covered with smaller fragments of basaltes, which appear to have been carried down from the steep sides of the mountain, and to have accumulated in the distriets of more gradual inclination. The size of these fragments is very various; in generat they linve a trapezoidal form, and a diameter of 6 or 8 inches. They are abundanty dispersed pver the ground which is in a state of culture 
and the natives here uniformly enploy them for inclosing their villages, gardens, \&c. \&c. Their fracture and composition is similar to that of many other basaltes found near our principal *voleanoes. With these lava is found, in many situations; it is almust generally exposed in the beds and at the banks of the rivtilets, either in solitary rocks or in collected groupes; it resembles the recent lava found in other parts of this Island; the color is black, the fracture vesicular, or similar to slags, and it emits when struk, the sound of brick. Lava of the same + kind was found, on my further route, at intervals in every part of the environs of this mountain, and has probably been ejected from the crater, like most of our recent lavas, in masses, which having congealed near the summit, rolled to the declivities in solid slaggy fragments. The elevation of the environs of the village of KaliBebber is still considerable-I observed the Thermometer on the morning of the 29 th October at 68 degrees of Fahrenheic's scale.

From here I proceeded in a souchern direc. tion continually towards the central valley. In the numerous ravines descending from the sides of the mountain Sundoro, which I crossed on the way to Kerteg, and consequently eastward to the valley which unites this mountain to thas of Sumbing, I noticed similar appearances. Besides the basaltic fragments which lay loose in large numbers at the bottom, thair sides exposed deep layers of Pudding-stone of a com-

- Exp. Cat. No. 69.

t Exp. Cat. No, $7^{1}$. 
pact texture, and of Tufa. They were both found solitary or in alternate strata. In a superior situation, and mixed with the decached fragments of Basaltes, the slaggy lava, above * mentioned, frequently occurred.

On the descent towards Kerteg; I regarded at a distance the continution of the numerous ridges stretching from the highest point of the range towards the central valley: they agree generally in form with those above described to the south of Batur, following aggregately a direction from North-east to South-west.

South of the central valley the ridges rise again to a considerable elevation. One very conspicuous point is here observed, denominated Gunung Koripan, or Damak yu by the natives: it has already been mentioned above, as constituting in the south the highest point, in opposition to Gunung Prow in the north. The districts of Gowong and Seln mane, and the southern portions of Ledog, which compose this part of the tract botmding the central valley? consist of an assemblage of ridges pursung a direction from east to west; in the vicinity of Kerteg several separate hills are scattered, without any regular disposition. The constitution of these is explained in a great measure by that of the ravines on this route. Rounded Basaltres, Pudding-stones and Tufa are strewed promiscuosly, or arranged in strata. The strean' of Begalo is here discerned, arriving from the western declivities of the mountain Sumbing, to' meet the Serayu about 9 miles to the westward.

* Exp. Cat. No. 71 and 72 ,

f Exp. Cat. No. 74 . 


\section{Essay, Ecc.}

From Kerteg the territory gradually ascends * towards the village of Rejo, situated at the western extremity of the valley, by which the mountains Sundoro and Sumbing are united; is is formed by the declivities of both passing into each other, and affords a very convenient passage between these mountains, whose summits are separ red only 10 miles; the situation of the Sumbing inclines from the Sundoro towards the South-east. No traces of a very recent eruption can be perceived on eicher at the present period; they are completely covered with vegetation, and their sides are excavated by deep ravines.

Of these two voleanoes the Sumbing has been the lorigest at rest. On leaving the valley an textensive propect opens in the eastward, and the volcanoes of Ungarang, of Marbabu and Marapi come successively into view, beyond and inrervening tract of about 20 miles, the appearance of which produces a most striking effect on the attentive traveller. No part of the Island, perhaps, affords, at one glance, a more extensive district covered uniformly by that species of hills, the form of which explains in a great measure their origin and ancient situation: here a numerous assemblage is dispersed over an extensive councry, the base of which has nearly the same level. The elevation of the separate hills is not considerable; they are in most cases conical or oblong, and rounded or blunt above. To a person arriving from the westward, this as-

- Exp. Cat. No. 73 Lava on this route.

t Exp. Cat. No. 76 Lava from the Mountain Sumbing. 
semblage exhibits an appearance not unlike the ocean in a violent state of agitation. The northern hills appear to form a connected ridge, stretching along the horizon, from the foot of the mountain of Ungarang towards the declivities of the mountain Prow. Their constitution is already explained by the description of the various central ranges on the preceding route; they are composed of the same materials; basaltes abound in all, bearing uniformly strong marks of attrition, as well in those fragments which remain on the declivities, as in those that have been carried down to the vallies and to the basins of the rivers and rivulets. In the vicinity of the Sundoro and Sumbing large fixed rocks project from the soil, and the detached fragments are very numerous; towards the eastern volcanoes the territory is covered, more deeply, by a reddish soil, and the basaltes in many cases exposed by sections of the hills, * indicates an incipient decomposi ion. Here some large rocks of this substance were also -found, composed of particles which separated into tables or slabs on the application of external force: they were often marked on the surface $f$ with parallel transverse lines.

The principal tiver pervading this territory, the Progo, arises from the norhern declivites of the Sundoro, and, after receiving numerous branches from this mountain, the Sumbing, and the declivites of the mountain Ungarang, flows in a nearly direct southern course towards the ocean : the most considerable of its eastern bran-

- Exp. Cat No 77 .

+ Exp. Cat No. 75. 
ches is the river Ello: both strenms retain for a considerable distance, a parallel course through an extensive basin (between the western and eastern series of volcanoes of this part of the Island) which conducts them to the south.

The districe just described, composed chiefly of irregular hills with intervening plains of no great extent, forms a large part of the province of Kadu: its elevation is considerable, and the temperature is favourably influenced by the vicinity of several of the largest mountains of the Island: in the west it consists of the declivities of the Sundoro and Sumbing, in the east of those of the mountain of Ungarang, of Marbabu and Marapi. Numerous rivulets and rivers arising from these afford it a very abundant supply of water.

Besides the common grains, rice, indian corn, \&c. which are largely produced, the territory is peculiarly favourable to the cultivation of various orher vegetables requiring a moist and elevated soil-the Tobacco is superior in quality to that of every other part of Java. The horses of the Kadu are well known: besides their other qualities, being bred on a stony tract, their hoofs possess, in general, a degree of soundness and toughness which renders them useful in travelling over stony roads.

Immediately beyond the basin of the river Ello, the territory ascends again towards the mountain of Marbabu, which constitutes the centre of the transverse series of volcanoes, consisting of the mountains of Ungarang, Marbabu and Marapi, to the east of the Basin of the Progo; the descriptiun of these is comprised in the continuation of the general mineralogical Essay. 


\section{CATALOGUE \\ of Explanatory Specimens.}

No.

1. Pebbles, from the river Progo, near Brossot.

2. Basaltic fragments, from the shore at the Cavern called Guwo-Dahar.

3. Calcareous rock, denominated Batu-churi by the natives, from the eminence above the Guwo-Dahar.

4. Hornstone-rock, from the eminence above Guwo-Duhar, carled Karang-Kuda.

5. Pudding - scone, from the cavern of Karangbollong, near the extremity of the hill, at the discharge of the river Chiching-goleng, from which the village and settlement has derived its name

6. Fragments of Basaltes, from the same.

7. Stone of watery deposition, lamellar, nodular, \&c. from the eminence between the discharge of the river Chiching-goleng and the village $\mathbf{K}$ rang-bollong.

8. Calcareous stone, found in large piles on the hill abcve Guwo-Nagassari.

9. Pudding-stones, from the e trance of the cave of Nagassari near the ocean.

10. White, friable, semi-decomposed lava dono. minated $P$ adas by the natives, bolonging to the substance named $T u f(z)$ found copiously on the hills on the route from Karang-bollong to Jittis: ( similar to No. 7.

II. Same substance ( $\mathrm{N}_{\mathrm{O}}, \mathrm{IO}$ ) more compact, forming Sand-stone found on the same route.

12. Hornstone porphyry, from the shore near Jingkla. 


\section{Essay, Ec.}

13. Calcareous spar, from the same place.

14. Black sand, from the beach opposite the discharge of the river Aya

15 . Pudding-stone from the foot of the hill near the place of passing the river Chichinggolent, on the road to the village of Karang. bollong

16. Stalacitic calcareous stone, from Rangka, employed in burning lime at Karang-bollong and neighbourhood.

17. Trapezoidal stone, of a greeni-h colour, the fracture resembling Sand-stone.

From Nuso-Brambang.

28. Cavernous lava, from Ujung agung on Nuso is rambang.

19. Pudding stone, from the same.

20. Rounded pebbles, from the shore near the deserted villages of Banjar and Brambang on the same.

21. Calcareous rock, from the point Tanjung Karang-pachi; from the same.

22. Calcareous roch, in extentive horizontal strata near Brambang, from the same.

23 Calcareous stone, from the foot of the hill near Karang-bolo, from the same.

24. Basaltic stones, from a rivulet near the village Brimbing from the same.

25. Sand-stone, from an extensive stratum at the banks of the river of Adiraja, in the district of Aya

26. Cavernous lava, from the discharge of the river Adi-rojo near the village Sawangan.

27. Lava separting into Rhomboidal fragments, from the foos of the hill Bedagangan, opposite to the village of Adi-raja, found at the banks of the river. 
28. Volcanic tufa, Padas of the Javanese, from Suko-rojo.

29. Volcanic tufa from Purwo-kerto.

30. Lavas from the basin of the river Banjaran, arising from the foot of the mountain of Tagal.

31. Lavas from the river Lo-Gowok, arising from the same mountain.

32. Lavas from the river Datar naer Ajibarang.

33. Lavas from the declivity souch of Ajibarang, and from various other situations in the neighbourhood of that village.

34. Stone of watery deposition, from a hill south-west of Ajibarang, near the banks of the river Tiajum.

35. Varieties of stone of watery deposition from the same place $\left(\mathrm{No} .34^{\circ}\right)$ in lamellae, nodules, tables, \&c. \&c.

36. Sand-stone from the same place.

37. Rock from the banks of the river Tiajum (resembling Amygdaloid) near Ajibarang.

38. Lavas from the road towards BojongTongo, in the district Prubolingo.

39. Varieties of Tufa, from the river Kelawing near Probolingo.

40. Variaus siliceous stones out of the same.

-41. Tufa from Kumutuk.

42. Compact liva from the same place.

43. Variegated stones, foundamong the pebbles in the bed of the river Serayu near Banjar.

44. Rounded voleanic pebbles, from the same place.

45 Fragments of aggregate rock, from the banks of the river ar the same place ( $N_{0.44 .)}$

46. Fragments from the large piles composing Gunung Lawer, consisting of tabular, \&rc, Basaltes. 
47. Sand-stone from the foot of the same (see No. 49.)

48. Stones of watery deposition, from the foot of the hill Pawinian, on the route from Banjar to Pagger - pella.

49. Reddish Sand-stone from the same.

50. Basaltes in a state of decomposition, from the Northern declivity of the eminence of Pagger-pella, on the road towards Karang Kobar.

$5^{1}$. Varieries of original Basaltes from the same.

52. Lava from the basin of the river Kali-urang near Pagger-pella (vesicular, belonging to the lavas of later eruptions.)

526.) Submarine lava from the same place (No. 52.)

53. Compact clay in tables, with angles rounded by attrition, from the same place.

$53^{b}$.) Stone consisting apparently of pecrified wood with sparry repositions.

54. Compact Pudding-stone (Amygdaloid) from the same (No. 52.)

55. Varieties of Sandstone from the same (No. 52.) fragments in thin lamellae, close and rectilinear, or concave-(apparently portions of spherical masses.)

56. Stones of watery deposition, from an eminence east of Karang-kobar.

57. Stones of watery deposition, found in extensive vertical strata at Kali lunyar.

58. Basaltes in a state of partial decomposition, from the section of an eminence on the near Kali-lunyar.

59. Stones of watery deposition, taken from an eminence berween Kali-lunyar and Nusupan. 60. Basaltes in a state of partial decomposition 
from an eminence enstward of Nusupan, on the road towards Batur.

6i. Basaltes found near Batur.

62.

63 .

64.

65. Varieties of lava found near Batur.

66. Partially decomposed Pudding-stone, from the road cowards the hil Pakerman.

67. Partially decomposed Basaltes, from the mountain Ptarangan, near flatar.

68. Reddish lava, on the road from Batur to Kon ng.

6.9. Basaltes from the rivulet (Kali-Iring) near the village Kali-Bebber.

7o. Fragment of an artificial stair, on the descent of the mountain Telogo - jebong or Prow.

71. Varieties of lava, from the foor of the mountain Sundoro, near the village of KaliBebber.

72. Varieties of lave from the same place ( $N_{0}$. 7r.) taken on the road between Kalibebber and Kerteg.

73. Var ieties of lava found on the road between Kerteg and Rejo.

74. Tolcanic Tufa between Kali-bebber and Kerteg.

75. Basaltic rock, separating spontaneously in tables, from the tract between Jitris and Pakkis-wiring.

76. Lava from the environs of mount Sumbing found near P k kis-wiring.

77. Basalic-stone in a state of incipient decompositioin, the surface being friable and earchy, from a hill on the roure berween Pakkis-wiring and Kamantran. 


\section{SECTION $1 \mathrm{~T}$.}

Catalogue of the Plants observed during t/ye preceding 'Tour.

\section{Class I. Monandria.}

Phrynium dichotomum Roxbgh. Scitam pl. As Res. vol.XI. [Willd Thalia cannæformis Bamban, of the Japanese Phrynium capitatum Angrik or Pattal Amornum Amomum Amomum Amomum Amomum Costus speciosus Alpinia Karawulu Teppus Unje-unje Wersa

Unker-unkeran

Paching

Kapollan

Class II. Diandria.

Jasminum multiflorum Poncho-sudo Justicía Betonica

Justicia Justicia Justicia Justicia Justicia chinensis Loro-wudu [Adasadasan Mungsa, Kalamulsa, of Justicia Gandarussa Justicia Justicia Justicia Justicia Hyssopifolia Justicia Justicia Insticia Piper Gubeba Piper

(see violacea Juru-demmung [Willd) Gondorusso-kebo Kelumba

Pinten

Terus or Gondorusso

Sukat-sawa

Sambang-lema

Teppu

Native name not deterditto ditto

Kumukus

Chabean 
Genus doubtful Genus doubtlul Sp. Patty-kulit or Barra Same Genus Same Genus Same Genus Same Genus Same Gunus Same Genus

Sp. II. Ketopra Sp. III. Ke-ji-warak or Brabas Sp. IV. Uwukwan

Sp. V. Sido-toppo

Sp. VI. Native name not deterSp. VII. ditto [mined.

\section{Class III. Triand ia.}

Valeriana

Genus doubeful Genus doubtful
Kettul or Chumplongạn

Komu-jingan

Nat. name not determinec.. (Herbary No. 772)

(Note-The Grasses are omitted in this Cutulogus.

Class IV. Tetrandiat.

Hed yotis foetida me

Hedyotis

Ixora

Ixora longifolia m

Callicurpa

Cissus

Pelhamia

Relhamia

Plantago asiatica

Embothrium

Embothrium

Gonocarpus

Chloreathus incon-
Simbu-an-Iemma

Attak

Sikattan

Tomandellan

Sangko

Banyon

Bollang

Singkil

Kuping-menyangan

Kendung

Kreuyes

D : reuran

Kres-tulang

Genus doubtini [spicuus A pi-api

Genus doubtful

Genus doubtful

Genes doubtful
Duduk-rayab

Putian of Gredean

Krema-gunung

Class V. Pentandria.

Heliotropium indicum Ge-ja-an

Myosotis

Tournefortia

Tournefortia
Patra-wisa

Angsang

Simbu-an-kaju 
Ophiorrhiza

Ophiorrhiza Mungos

Plumbago Rosea

Gonvolvulus pellatus

Convolvulus

Convolvulus

Convolvulus nervosus

Convolvulus vitifolius

Convolvulus

Campanula

Nauclea

Nauclea

Scaevola Lobelie

Lobelia

Lobelia

Lobelia

Coffea

Morinda citrifolia [culta) Wongkudu

Morin. (varictas cítrifol-

Mussaenda frondosa

Mirabilis Jalappa

Physalis

Solanum

Solnuum verbascifolium

Ardisia littoralis $m$.

Ardisia

Ardisia

Ardisia

Cordia

Cordia Mysa

Tectona grandis

Rhamnus

Rhamnus

Rhamnus

Mangifera (var. indic.)

Viola

Impatiens cornuta

Impatiens trillora

Leea

Leea sambuciaa
Jokko-tuwo

Patty-Uler

Mud-ja

Blaran

Kang-kung-Kang-

Pes-oaprae [kung-an

Native name not deter-

Sampar-kidang

[mined

Sukat-en-jari

Chautel-wessi

Kleppu

Wudelan

Raggi-Jajar

Bawangan

Jambon
Walli-kaddeb

Kembang-pukkul-ampat

Chi-plu-an

Rantí

Tetter

Lempennen

Lempenni

Walluk

Kendal-rambat

Kendal

Jati

Kandri

Gondopuran, Kamaion

Pepe-lout, Singkil-

Po

Lenga-tangan

Pachar-banyu

Lengki, Kayu-bowaya 
Leea acquata

Vitis stercoracea $m$

Aegiceras majus

Greng-guta

Achyranthes

Achyranthes sangvino-

Celosia castrensis [lenta

Rouwolfia

Cerbera Manghas

Tabernaemoutana

Plentru

Binteru

Asclepias gigantea

Pule

Apocynum frutescens Raggi

Natural order con-?

tortce Genus doubiful\}

$$
\begin{array}{lll}
\text { ditto ditto } & \text { Oyod-kepitting } \\
\text { ditto ditto } & \text { Ri-bettu or Kelongkit } \\
\text { ditto ditto } & \text { Pottong-assu } \\
\text { ditto ditto } & \text { Tipis-kulit } \\
\text { hotria } & & \text { Sekulan } \\
\text { hotria } & & \text { Wattuk }
\end{array}
$$

Psychotria

Psychotria

Psychotria

\section{Psychotria}

Psychotria

Hydrocotile asiatica

Caucalis

Sambucus

Basella

Mahernia

Polyscias

Polyscias

Polyscias

Polyscias

Polyscias

Polyscias

Polyscias

Genus doubtful

Genus doubtful

Genus doubtful

Genus doubtful

Genundoubtful Sp. I. Delu-alas

Native name not deter-

Kudon [mined

Pung-ga-gan Panigo-

Kettul

[wong

Kenchur

Wesnu

Gorang-irêng

Gorang-klanting

Chelangan, Tanganan

Oyod-tingan

Puchangan

Sanhang, Pampung

Gigil, Grabusan

Tembessen, Bimossetti

Telos-kepollo

Bangkong, 'Tempo-

Duduk-agung [wiyung

Sanse Genus Sp. II. Tiba-bunatil, Gemblek 
Genus doubtul Genus doubtful Genus doubtful Geuns doubtful Genus doubtful Genus doubtful Sage Genus Same Genus Genus doubtful Genus doubtful Genus doubtful Genus doubtful Genus doubtful Sp. I. Same Genus Sp. II. Genus doubtful Genus doubtful Genus doubtful Genus doubtful
Talen

Gundo, Gudean

Mandillan, Gambiran.

Gorang-pute

Man i- Ingas, Rengas

[fera) Kemiri-seppet

Pen-jalinan

Kayu-sapi

Sekkar-Jalla, Mallattan

Jeruan, Ri-kuwut

Dukut-Serru

Native name not deter[mined

Sala-N yowo (Sp. II.)

Kayu-tyn, Itil-biru Sekulan, Kiput.

Class VI. Hexandria.

Trandescantia

Crinum asiaticum

Patungan

Bakung

Curculigo

Dracaena ensifolia Lin :

Dianella nemorosa La-

[mark Tog-gare

Nyangko
Calamns Rottang

Bambusa

Genus doubtful

Genus doubtful
Urean

Rottan-mas w with many oRottan-cha-

[ching] ther varieties

Pring-many varieties

Lompongan

Oger-oger

Class VII. Heptandria.

Jonesia.

Belanak

\section{Class VIII. Octandria}

Allophylus

Clausena

Klayu

[kodok

Clausena excavata (Burm: Tikussan 
Dodonaea

Xylocarpus Granatum

Schmiedelia racemosa

Schmiedelia

Polygonum

Polygonum chinense

Polygonum orientale

Polygonum batbatum

Palygonum

Genus doubtfal

Genus doubtful

Genus doubtful
Kesse

Nyeri, Jombo

Chukilan

Badot

Barang

\section{Class IX. Enneandria.}

Laturus

Laurus

Lauru's

Laurus

Laurus

Laurus

Laurus

Cassyta filiformis Sukat-kremi

Kayu-jey or Nyampa-

Krangeang [gedobog

Pachol

Teja

Wurn

Wuru-kunyit

Class X. Decandria.

Cassia obtusifolia

Cassia alata

Keteppeng

Cassia

Guilandina

Gaertnera racemosa

Keteppeng-kebo

Wringinan

Wewe

Kakkas

b.,-a variety with winding stem: Kakkas-rambato Cynometra ramillora

Cynometra

Adenanthera

Limonia

Sandoricum indicum Sentul

Sandoricum

Sentul
Keddayu
Seng-gan

Melastoma malabathrica Seng-gani

Melastoma speciosa $m$

Mielastoma

Mielastoma

Témbagan

Keppel

Ipil

Saga-kebo 
Melastoma

Casearia

Arbutus

Arbutus

Arbutus

Andromeda

Dais octandra

Cerastium

Oxalis corniculata

Robergia

Spondias

Banisteria

Genus doubtful

Genus doubtful

Genus doubtiul

Genus doubtful
Pari-jotto

Balung

Manis-rejo

Girmat, Rangutan

Kembang - Kepitting,

Pruwoko, Pruwosote[Gumen

Siri-jawan, Lawe

Bro-jo-lintan

Somang-gi

Popouivan

Rou

Re-mas

Ares, Kayu-gedang

Jirekan, Klimo-konchir.

Ri-Kengkeng

Ampet, Sing-ganen

\section{Class XI. Dodekandria.}

\section{Bassia}

Rhizophora

Rhizophora

Triumfetta

Kleiuhofia hospita

Sterculia Balanghas

Sterculia foetida

Sterculia

Serculia
Kommit

Bakko

Tanchang

Timoho

Antap Kayu-lumut.

Keppo-jangkang

Dok-dokkan

Cluu-chuk-wang

\section{Class XII. Icosandria.}

Psidium pyrifernm

Engenia racemosa

Engenia

Engenia

Engenia

Engenia

Engenia

Sonneratia acida

Sonneratia (variety of
Jambu-klutu

Putat

Putat-tresse

Song-gom, Bedér

Telampok

Jambon

Glunden, Besole

Gowok, Klessem.

Bogem

the preceding) _- - Prapat 
Sesuvium portulacast- Krokot, Gelang

Spiraca

Rubus moluccanus

Rubus parvifolius

Rubus

Fragaria [rum Wari-gunung

Brembetc

Uchi-uchi

Grung-gung

Saprahan

Class XIII. Polyandrid.

Calophyllum Inophyl- Nyampluing

Elaeocarpus seirata [lumJenitri

Microcos paniculata Delluwak

Alangium hexapetalum Komlentoro

Uvaria florida $m$

Uvaria

Uvaria

Uvaria

Annona

Dillenia

Dillenia

Ranunculus

Kalak

Native name not deter-

Kalak-prit [mined

Chempoko-baros

Chellalak

Sempu

Gregel

Genus doubtful Sp. I Umbel-umbellan

Same Genus Sp. II Umbel-umbelan-kebo

Same Genus Sp. III Umbel-umbellan-prit

Same Genus Sp. IV Umbel-umbelan-abang

Genus doubtful Native name not deter-

Genus doubtful Sp. I Wadang, Bayur [mined

Genus doubtful $\mathrm{S}_{\mathrm{p}}$. II Walang

Genus doubtful Jirak

Genus doubtful

Gobedan

Genus doubtful

Gudean, Sadang

Class XIV. Didynamia.

Mentha auricularia

Leonurus

Betonica

Stachys

Stachys

Ballota disticha

Seutellaria

Ocymum
Kleng-leng-an

Jung-gul

Sangketan

Slangking

Sangket 
Ocýmum

Ocymum

Ruellia antipoda

Volcameria inermís

Volcameria serrata

Volcameria

Clerodendium

Thumbergia

Vitex trifolia

Vitex

Vitex

Vitex

Bignonia

Bignonia

Bignonia indica
Mellitis

Ruellia Anagallis

Wrikki

Dillem

Krok-nangsi

Krok-lawơk

Gambir-lout

Sri-gung-gu

M lati-alas, Lorunko

Trembuku

Chuchuk-dandang

Lagundi

Ket lêng

Laban

Ampu

Kappal

Pichisan, Kapallan

Wangli

Jeru-ju

Kri-y k

Class XV. Tetradynamia.

Sinapis sativus

Cleome

Sawe

Komandellan

Class XVI. Monadelphia.

Bombax heptaphyllum Randu-şung

Sida retusa

Sidoguri

Ureva lobata

Hibiscus Abelmoschus Waron

Hibiscus Surattensis Ri-larat; Usi-usi

Hibuseus

Genus doubtful

Munung, Wining

Class XVIt Diadelphia.

Polygala pendula $m$ Native name not deterPolygala

Abrus precatorius

Crotalaria

Saga

ditto ditto [mined

Orrok-orrok

Crotalaria

Erythrina Coralloden- Chang-kring Erythina [drum Dadap 
Dolichos

Galedupa arborea

Galedupa (scandens)

Hedysarum (yar. unbellat?) Belanakkan

Hedjsarum strobiti- Gattak

Hedysarum : [ferum Gudean

Hedjsarum

Hedjsarum

Lotus

Somang-gi-guntung

\section{Class XVIII. Polyadelohia.}

Durio Zebethinus

Munchausiaspeciosa- ( $\mathrm{La}-$

Duren

gerstroc mia Regince)- Wungn

Hypericum Unje-unje

Class XIX. Syngenesia.

Sonchus

Sonchus

Lactuca

Bidens bipinnata

Ethulia

Eupatorium

Artemisia

Gnaphalium

Sumbiêng

Kaju-Rono

Gnaphalium

Conyza

Conyza.

Senecio

Aster

Verbesina

Tespong

Verbesina biflora

Saprag

Te-gunung (mollo Rodo - mollo, Godon

Sendiva

Sembung

Trassen

Tegel-kiju

Verbesina

Sphaeranthus globosus

Genus Doubtul (Comp. Sembung (with arbored Genus Huberlia) ous stem)

\section{Class XX. Gynandria.}

Orchis

Stilinga Bunitus

Native name not deter-

Wuni 
Epidendrum pyramida-

tun $m$ - - - Bawangan

Epidendrum (Herbario No. 766)

Epidendrum (Herbario No, 767 )

Epidendrum (Herbario No. 765 )

Epidendrum (llerbario No. 764)

Epidendrum (Herbario No. 765 )

Epidendrum (Herbario No, 763 )

Class XXI, Monocia.

Artocarpus incisa

Artocarpus

Artocarpus

Cussuarina

Hernandia sonora

Urtica longifolia

Urtica

Urtica

Urtica

Urtica candicans

Urtica

Urtica aestuans

Urtica

A maranthus

Epibatherium

Arum

A rum

Arum

Arum

Begonia

Caryota urens.

Fagus

Quercus

Areca

Phyllauthus urinaria

Phyllanthus

Phyllanthus

Thyllanthus

Croton

Croton
Sukkon

Purut

Bendo

Chomoro

Kemixen

Lunyax.

Jaraug

Turang-rambat

Menehogan

Ramen

Simpel-wuwi

Kemadu 2 /mined

Native name not deter-

Bayem

Sluru:

Banga

Dadag, Slempat

Klatta

Nampir

Trembilungan

Kendiru, umbu-enduru

Sarangan

Pássing

Jaubi Pi-ji

Mer, Immen, Tomtoman

Katu-kebo

Dimpul

Blo-ketapu

Kepét, Salsagi 
Croton

Croton variegatum

Croton

Croton coccineum $m$

Ricinus Mappa

Ricinus

Jatropha curcas

Aleuritis triloba

Guetum (E: volubilis)

Momordica Luffa

Bryonia foetida $m$

Natural order Cucurbi-

taceae, Genus doubtful Bolu-paît

Ditto ditto

Ditto ditto

Ditto ditto

Genus doubtful

Genus doubtful

Genus doubtful (among

the Palmac Gligen, Mendu

Genus doubtful do. do. Wergo

Geuus doubtful do. do. Aren

Class XXII. Dioedia.

Pandanus littoralis

Pandanus

Cycas revoluta

Excaccaria Agallocha

Brucea

Antidesma

Antidesma

Smilax China

Smilax (caule inerme)

Flacourtia

Flacourtia

Nepenthes

Myrustica

Sutherlandia littoralis

Genus doubtful

Genus doubtful
Pandan Passir

Soge-mane

Pakis ta- $\mathrm{ji}$

Kayu-Gitta

Patty-lallar

Andi-andi

Andi-andi-an

Ri-wonno

Godong-wonno

Rukkem [mined

Native name not deter-

Kalok-chikko

Kayu-ra

Dungun

Kallas. Gesta

Suru-kebe 
Essay, Ec.

Genus doubtful

Genus doubtlul

Genus doubtful

Pu-chung [guyu

Tembaga, Teng-gulung-

Serrut

\section{Class XXIII. Polygamia,}

Parietaria

Celtis orientalis

Terminalia

Mimosa

Mimosa

Mimosa

Mimosa

Mimosa

Mimosa

Mimosa

Mimosa

Mimosa

Mimosa

Ficus

Ficus

Ficus

Ficns

Ficus

Fieus

Ficus

Ficus

Ficus

Ficus

Ficus

Ficus (variety of the pre-Pang-gang

Ficus

Ficus

Ficus

Ficus
Derrês

Angrung

Ketappan

Bangkong

Jengkol

Goleng

Kedawung

Komlandingan

Pette

Sengon

Seppat

Tekkik

Werru, Wangka!

A war-awar

Bulu

Bulu-empan

Gondang

Karet

Konyal

Kebbêk

Lo

Luwing

Rempelas

Weringin

[ceding) Randan-

Wiloddo

Se-pre

Pellus

Class XXIV. Cryptogamia.

Ord : II. Filices or Ferns

$\mathrm{O}_{\mathrm{P}}$ hrioglossum (see Hydroglossum willd) Her[bario No. 706 
Acrostichum Herbario No. 662 Acrostichum ditto No. 75 t Acrostichum ditto No. 829 Pteris Pteris Pteris Pteris Pteris Blechnum dicto No. 634 ditto No. 672 ditto No. 733 ditto No. 762 ditto No. 819 ditto No. 9 -6 Blechnum ditto No. 755 Blechnum ditto No. 753 Blechnum ditto No. 820 Blechnum ditto No. 821 Blechnum ditto No. 853 Hemionitis ditto No. 740 Hemionitis ditto No. 745 Hemionitis ditto No. 752 Meniscium ditto No. 653 Meniscium ditto No. 760 Meniscium ditto No. 818 Asplenium ditto No. 674 Asplenium ditto No. 638 Asplenium ditto No. 738 Asplenium ditto No. 751 Asplerium ditto No. 822 Asplenium ditto No. 324 Asplenium ditto No. 82.5 Asplenium ditto No. 826 Asplenium ditto No. 827 Davalia ditto No. $85 x$ Davallia ditto No. 855 Davallia ditto No. 856 Polypodium dizto No. 673 Polypodium ditto No $7 . \overline{4}$ Polypodium ditto No. 759 Polypodium ditto No. 743 Polypodium ditto No. 744 Polypodium ditto No. 745 Polypodium ditto No. 757 Polypodium ditto No. 761 


\section{tissyy, E?c.}

Polypodium Herbario No. 835 Polypodium ditto No. 856 Polypodium ditto No. 857 Polypodinm ditto No. 838 Polypodium ditto No. 839 Polypodium ditto No.84o Polypodium ditto No. 341 Polypodium ditto No. 843 Polypodium ditto No. 84.3 Polspodium ditto No. 84 4 Polypodium ditto No. 345 Polypodium ditto No. 846 Polypodium ditto No. 347 Polypodium ditto No. 848 Polypodium ditto No. 849 Polypodium ditto No. 850 Polypodium ditto No. 866 Polypodium ditto No. 867 Polypodinm ditto No. 868 Polypodium ditto No. 869 Polypodium ditto No. 870 Polypodium ditto No.871 Polypodium ditto No. 872 Polypodium ditto No. 873 Adianthum ditto No. 756 Adianthum ditto No. 759 Adianthum ditto No.830 Adianthum ditto No. 831 Lonchitis ditto No. 741 Lonchitis ditto No. 742 Scolopendrium ditto No. 828 Triclromanes ditto No. 747 Trichomanes ditto No. 749

Trichomanes ditto No. 750 Trichomanes ditto No. 755 Trichonianes ditto No. 832

3 Genera related to the Ferns. Iycopodium Herbario No. 737 Lycopodium ditto No.817. 
Essciy, 8ic:

Iycopodirim ditto No. $85 \mathrm{t}$ Lycopodium ditto No. 859 Lycopodium ditto No. 853 Lycopodium ditto No. 854 Lycopodium ditto No. 865

Order III Musci-Mosses.

Gents not determined Herbario No. 857

$\begin{array}{lll}\text { Dittc } & \text { ditto } & \text { No. } 858 \\ \text { Ditto } & \text { ditto } & \text { No. } 859 \\ \text { Ditto } & \text { ditto } & \text { No. } 860 \\ \text { Ditto } & \text { ditto } & \text { No. } 861 \\ \text { Ditto } & \text { ditto } & \text { No. } 862 \\ \text { Ditto } & \text { ditto } & \text { No. } 864 \text { s }\end{array}$




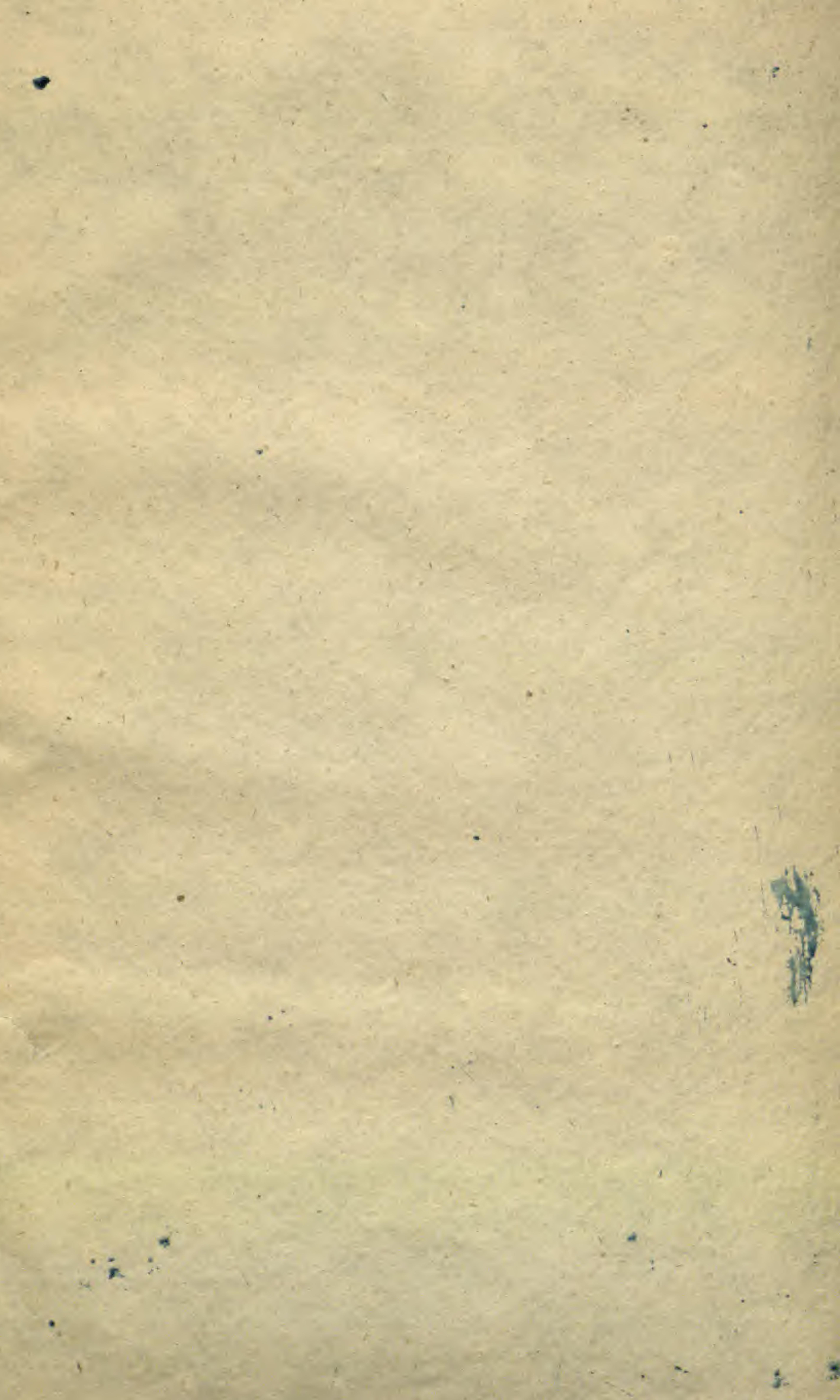

.

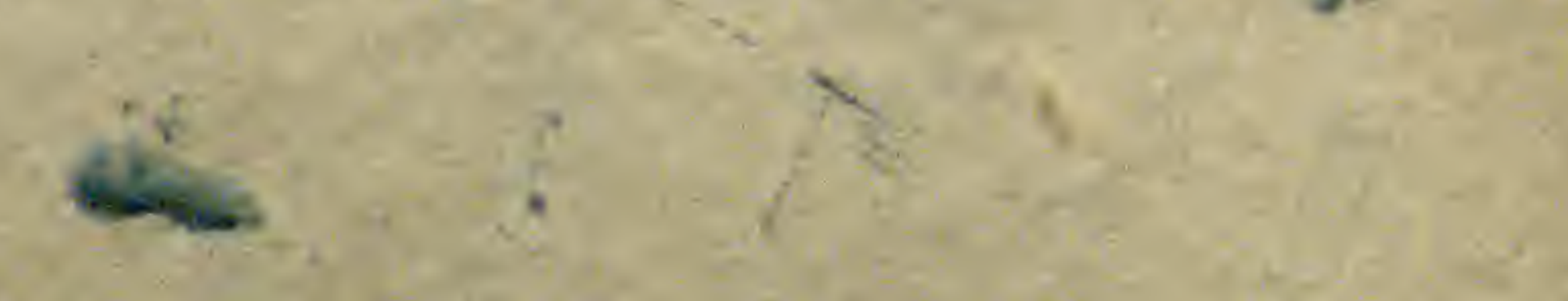

